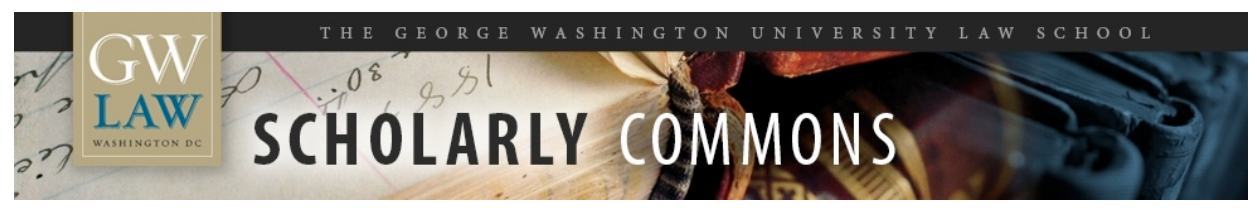

GW Law Faculty Publications \& Other Works

Faculty Scholarship

2021

Lessons from Quality Shareholders on Corporate Governance

Practice, Research and Scholarship

Lawrence A. Cunningham

Follow this and additional works at: https://scholarship.law.gwu.edu/faculty_publications

Part of the Law Commons 


\title{
LESSONS FROM QUALITY SHAREHOLDERS ON \\ Corporate Governance Practice, ReSEarch AND SCHOLARSHIP
}

\author{
Lawrence A. Cunningham*
}

\begin{abstract}
This Article presents original data and analysis addressing an understudied force in corporate America: the most patient and focused shareholders. Great attention has been devoted to shortterm trading on the one hand and diversified index funds on the other, ${ }^{l}$ but scant attention has been focused on long-term concentrated investors. The George Washington University has been redressing this problem through a research initiative focused on such buy-and-hold stock pickers, whom Warren Buffett long ago dubbed "quality shareholders." $G W$ 's Quality Shareholders Initiative ("QSI") is pleased to present highlights of the initial installment of this work in this Article in the Business and Finance Law Review at the George Washington University's Center for Law, Economics, and Finance.
\end{abstract}

\section{TABLE OF CONTENTS}

ABSTRACT

INTRODUCTION.

I. THE QUALITY SHAREHOLDER SEGMENT ………………..................

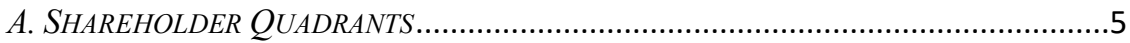

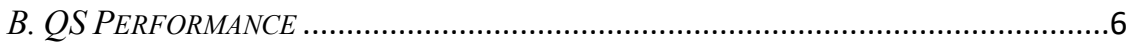

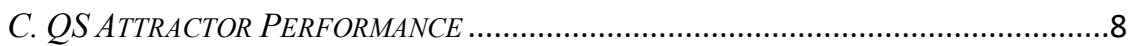

II. IDENTIFYING QSS AND THEIR ATTRACTORS.......................................10

III. POLICIES AND PRACTICES .....................................................................19

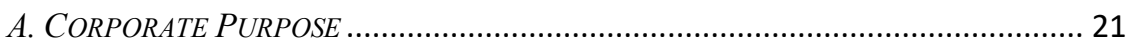

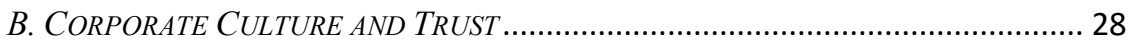

C. GOVERNANCE FLEXIBILITY OR RIGIDITY.................................................... 30

* Henry St. George Tucker III Research Professor, George Washington University Law School; Founding Faculty Director Quality Shareholders Initiative (QSI) and Faculty Director, Center for Law, Economics and Finance $(C-L E A F)$. For research and other assistance preparing this Article, thanks to the team behind the QSI, including Mareah Younes, David Templeton, Gia Arney, Annie Ezekilova, and Lori Fossum.

${ }^{1}$ See, e.g., Jill E. Fisch, Assaf Hamdani \& Steven Davidoff Solomon, The New Titans of Wall Street: A Theoretical Framework for Passive Investors, 168 U. PA. L. REV. 17 (2019); Assaf Hamdani \& Sharon Hannes, The Future of Shareholder Activism, 99 B.U.L. REV. 971 (2019).

${ }^{2}$ See Edward B. Rock, Shareholder Eugenics in the Public Corporation, 97 CORNELL L.

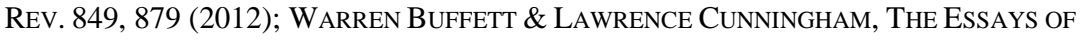
WARREN BUFFETT: LESSONS FOR CORPORATE AMERICA 185-188 (5th ed. 2019).

${ }^{3}$ C-LEAF InITIATIVES: QuALITY SHAREHOLDERS INITIATIVE, https://www.law.gwu.edu/cleaf-initiatives (last visited Sept. 23, 2021).

November 2021 Vol. 5 No. 1 
D. DIRECTOR DIVERSITY 39

E. WHAT ELSE MATTERS? 43

IV.

\section{INTRODUCTION}

Our original motivation for the QSI arose from the growing size and power of institutional investors, among the most important contemporary trends in American corporate life. Lively debates contest whether such powerful investors have the right vision or conviction to faithfully discharge the trust so many Americans have placed in them. ${ }^{4}$ On vision, participants have long debated whether investors, especially activists, are too short-term oriented to enable managers and markets to maintain a long-term view. ${ }^{5}$ On conviction, debaters ask whether certain kinds of investors, particularly passive indexers, have sufficient incentives to actively monitor managers to promote performance and accountability. ${ }^{6}$

These are vital discussions in corporate America, implicating fundamental questions of the balance of power between directors and shareholders as well as among shareholders. As such, they stoke numerous sub-debates on every aspect of corporate governance, such as board structures, director-officer relationships, shareholder rights, and corporate purpose - all with wide-ranging effects on the national economy. ${ }^{7}$ Although such debates are sophisticated, increasingly data-driven, and involve overlapping participants, they suffer from a false binary: the horizon debate juxtaposes short-term against long-term but mutes conviction, while the conviction debate juxtaposes passive against active investment styles but mutes horizon.

In fact, however, while time horizon and relative conviction are important, neither alone captures the nuanced reality of investor behavior which involves both features simultaneously. The QSI incorporates such concurrent analysis of horizon and conviction by incorporating both as embodied in quality shareholders ("QSs").

While contemporary data suggest that a large plurality of institutional shareholders qualify as short-term and another plurality as indexers, the QS cohort remains a significant force in market and corporate behavior. It should accordingly be given an important place in debates over horizon and conviction - as well as all areas concerning shareholder voice.

${ }^{4}$ See, e.g., Elisabeth de Fontenay, The Myth of the Ideal Investor, 41 SEATTLE L. REV. 425 (2018).

${ }^{5}$ See Marcel Kahan \& Edward B. Rock, Hedge Funds in Corporate Governance and Corporate Control, 155 U. PA. L. Rev. 1021, 1083 (2007); John C. Coffee, Jr. \& Darius Palia, The Wolf at the Door: The Impact of Hedge Fund Activism on Corporate Governance, 41 IOWA J. CORP. L. 545, 572-573 (2016).

${ }^{6}$ See e.g., Lucian A. Bebchuk \& Scott Hirst, Index Funds and the Future of Corporate Governance: Theory, Evidence, and Policy, 119 CoLum. L. REv. 2029 (2019).

${ }^{7}$ E.g., John C. Coates, IV, The Future of Corporate Governance Part I: The Problem of Twelve (Harv. Pub. L. Working Paper No. 19-07, 2018), www.ssrn.com/abstract=3247337. 
The QSI's efforts in this regard began with the book, Quality Shareholders, outlining the motivation, history and preliminary data on the cohort and the companies and practices that attract them. ${ }^{8} \mathrm{~A}$ series of journal articles followed.

The first made the case to empower $\mathrm{QSs}^{9}$ as a contribution to the broader debate about the optimal general distribution of corporate power between managers on the one hand and all shareholders as a group on the other. ${ }^{10}$ The second explored a dozen corporate policies that attract QSs, adding to the literature on how companies shape their shareholder base. ${ }^{11}$ The third elaborated a proposal for a separate precatory vote of QSs as a class when boards propose actions otherwise requiring or warranting a general shareholder vote, such as where by custom a vote of the minority shareholders is held. ${ }^{12}$ While these publications were being produced, QSI's research continued to search for factors that attract or repel shareholders to particular companies.

Ongoing empirical research generally involves comparing the QSI ranking of companies by QS density with various rankings of companies and their policies. For instance, QSI has considered correlations between QS density and corporate statements of purpose, capital allocation prowess, reputation for trustworthiness, board structure and diversity, shareholder voting rights, corporate culture, and brand strength. ${ }^{13}$ The data tend to challenge conventional wisdom on many practices, suggesting that the views of QSs differ from those held by many in the governance establishment.

All of this research showcased by the QSI is propitious as new research casts doubt on the reliability of databases long-used to debate corporate governance. ${ }^{14}$ For at least two decades, such debates have been shaped by a body of empirical work led by that of finance professors Gompers, Ishi and Metrick. ${ }^{15}$ Using data created by the Investor Responsibility Research Center (IRRC, now part of Institutional Shareholder Services or ISS), they found that investors generally fare far better investing

\footnotetext{
${ }^{8}$ Lawrence A. Cunningham, Quality Shareholders: How the Best Managers ATTRACT AND KEEP THEM (2020).

${ }^{9}$ Lawrence A. Cunningham, The Case for Empowering Quality Shareholders, 46 B.Y.U. L. REV. 1 (2020).

${ }^{10}$ E.g., Lucian Arye Bebchuk, The Case for Increasing Shareholder Power, 118 HARV. L. REV. 833 (2005); Stephen M. Bainbridge, Director Primacy and Shareholder Disempowerment, 119 HARV. L. Rev. 1735 (2006); William W. Bratton \& Michael L. Wachter, The Case Against Shareholder Empowerment, 158 U. PA. L. REV. 653 (2010); Jesse M. Fried, The Uneasy Case for Favoring Long-Term Shareholders, 124 YALE L. J. 1554 (2015).

${ }^{11}$ Lawrence A. Cunningham, Cultivating Quality: Time to Revise and Update the Shareholder Cultivation Literature, 15 Оніо ST. Bus. L.J. 85 (2021).

${ }^{12}$ Lawrence A. Cunningham, Ask the Smart Money: Shareholder Votes by a "Majority of the Quality Shareholders", 55 U.C. DAVIS L. REV. 1, 1 (2021).

${ }^{13}$ See infra Part III.

${ }^{14}$ Jens Frankenreiter, et al., Cleaning Corporate Governance, (U. Pa. L. Rev., Working Paper No. 738/2021) https://ssrn.com/abstract=3796628.

15 Paul A. Gompers et al., Corporate Governance and Equity Prices, 118 Q. J. Econ. 107, 125-29 (2003).
} 
in "democratic" than "despotic" companies. Dubbed the G-Index, researchers proliferated numerous variations using similar datasets. ${ }^{16}$ Influential advisors to large institutional investors, such as ISS and MSCI, commercialized recommendations based on such data.

But according to a major study by law professors Jens Frankenreiter, Cathy Hwang, Yaron Nili, and Eric Talley, this research contains many errors. ${ }^{17}$ Coders misinterpreted source material on some basic features, such as whether a company had dual class shares, a staggered board, or supermajority voting. ${ }^{18}$ Among dramatic effects of correcting for these errors erases, most of any return premium to democratic compared to despotic companies. ${ }^{19}$

The new study and database promise better understanding for investors on key topics in corporate governance. There are many hypotheses to be tested, including those surfaced by the QSI. For example, the QSI data suggests governance provisions operate differently in varying contexts, so that what's good for one company is bad for another. It also suggests that many factors well beyond those treated as central in recent decades matter more. If the Frankenreiter study creates a fresh slate for corporate governance debates, then the QSI research offers a timely contribution to the new direction of this research.

In this Article, we summarize some aspects of the previously reported research and collate the many hypotheses and correlation test results applied since the most recent publications. This draws together parts of the book, research articles and columns.

Part I reviews the literature on segmenting a shareholder base, along with observations on debate over whether any of various active investment strategies, such as those embedded in QSI, are capable of outperforming passive indexing on a systemic basis. Part II reports on the many different research methods that can be used to identify QSs and the companies that attract them. Dozens of techniques are presented, culled from both existing secondary sources as well as original QSI data crunching. Notably, the multipronged effort tends to converge in identifying the same investors and companies across different sources and measures. Part III, the heart of the Article, presents a series of tests for the correlation between a variety of corporate practices and the attraction of QSs. This contributes a fresh view on many overlooked or underappreciated topics.

\section{The QuAlity SHAREHOLDER SEGMENT}

As background, this Part offers a definition of quality shareholders and identifies contrasting cohorts. It then briskly reviews some features of

\footnotetext{
${ }^{16}$ See K.J. Martijn Cremers \& Simone M. Sepe, The Shareholder Value of Empowered Boards, 68 StAn. L. ReV. 67, 132-135 (2016).

${ }^{17}$ See Frankenreiter, et al., supra note 14 (manuscript at 3).

${ }^{18} I d$. (manuscript at 33).

${ }^{19} \mathrm{Id}$. (manuscript at 39$)$.
} 
the QS cohort along with highlights of ongoing debate in the financial community about whether such a strategy can be viable in terms of shareholder returns. Such preliminary framing will set the stage for Part II's reports on methods of identifying QS and Part III's engagement with what they prioritize.

\section{A. Shareholder Quadrants}

This research first delineates multiple shareholder types based on both horizon and conviction. To visualize this, shareholder cohorts can be identified using a 2 × 2 diagram arraying investment conviction across the top and investment horizon down the side. The result reveals combinations of conviction and horizon, as shown in Table I.1.

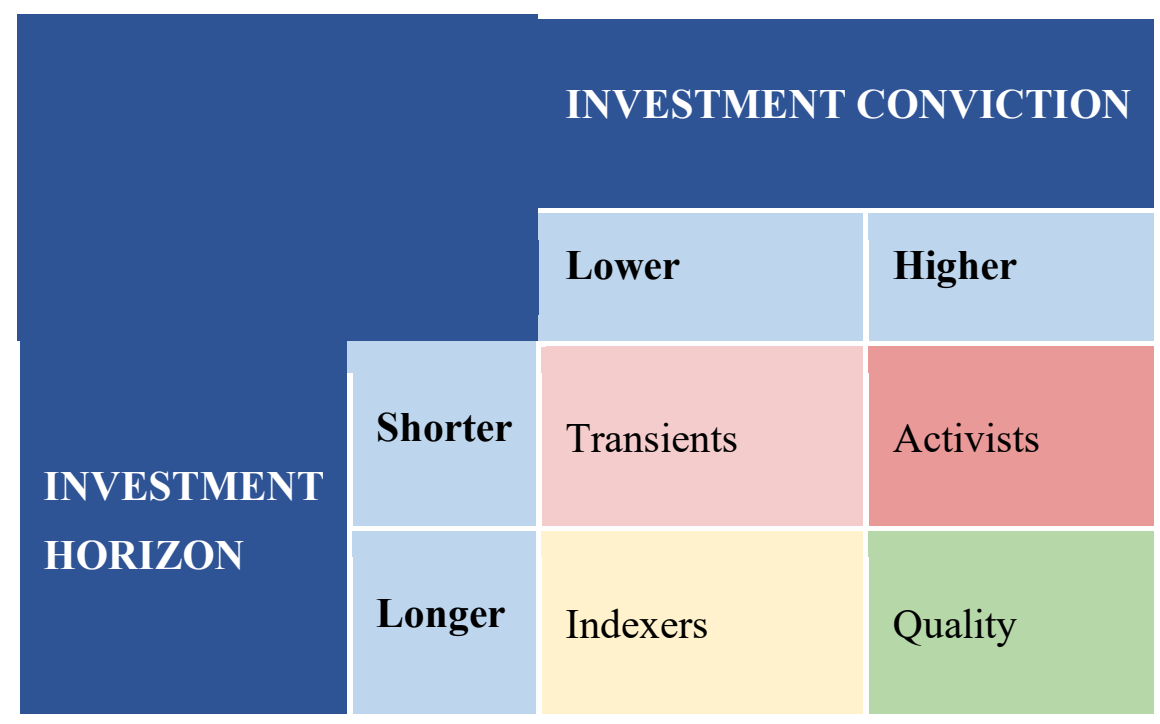

Table I.1: The 2 x 2 Diagram

To animate the approach, descriptive names are assigned: transients to shorter-term/diversifiers; indexers to longer-term diversifiers; activists to shorter-term concentrators; and quality to longer-term concentrators. Investment conviction is measured by the degree of an investor's portfolio diversification versus concentration, with lower conviction meaning the most diversified portfolio - epitomized by index funds. Investment horizon is measured by the investor's average holding period in its investments.

Delineating the different criteria enables consideration of the tradeoffs. That will help managers attract shareholders they desire and policymakers tailor public policy, in each case ideally towards long-term and informed investors.

The stakes are high, as these debates touch fundamental issues in corporate governance. The rise of institutional investors raised the volume of shareholder voices on a wide range of matters, from director elections to say on executive pay and influence on corporate proposals spanning from 
climate change and gender diversity to strategic direction and corporate priorities. $^{20}$

\section{B. QS Performance}

This Article does not investigate or make claims concerning investment strategy or portfolio construction, nor contend that QSs systemically achieve superior investment results. Accordingly, no data have been sought or presented that would support such assertions. However, such topics are inevitably raised when considering the QS approach of patient focus, compared to short-term trading, a pure index, or any other of innumerable investing styles. Some brief probing of the topic has therefore been done and reported.

At the most general level, ongoing debate in the literature and practice on investing rages around whether stock indexing or stock picking is a superior strategy, often delineating further into types of broad indexes (by size, sector, or geography) with stock pickers competing against that benchmark. ${ }^{21}$ A foundational contribution to that debate is a 1997 article by Mark Carhart, then a professor of finance at the University of Southern California, finding no evidence of successful mutual fund stock pickers. ${ }^{22}$

Ensuing research contributed to what became conventional wisdom, such as: average active funds underperform the market after fees $;{ }^{23}$ top fund performance doesn't persist; ${ }^{24}$ and, while some managers are skilled, few deliver on that value for customers after fees. ${ }^{25}$ Yet debate continues - and

${ }^{20}$ See Luis A. Aguilar, Comm'r, U.S. Sec. and Exch. Comm'n, Address at the Georgia State University Center for the Economic Analysis of Risk Workshop: Institutional Investors:

Power and Responsibility (April 19, 2013) (finding that institutional investors have a voice when it comes to "the quality and diversity of Boards of Directors, as well as compensation structures and concerns about the runaway growth in executive pay"); Morgan LaManna \& Rob Berridge, Acting on the Climate Crisis, 8 Proxy MonThly 8, 8 (2021), https://www.proxyinsight.com/wp-content/uploads/dlm_uploads/2021/08/Proxy-MonthlyJuly-2021.pdf ("[i]n this record-setting proxy season, investors won majority votes on 14 climate-related shareholder proposals in both the U.S. and Canada, more than double last year's winning votes."); Lyuba Golster et al., Heads-Up for the 2021 Proxy Season: Focus on Diversity Disclosure, WeIL GovernanCE AND SECURITIES WATCH (March 22, 2021), https://governance.weil.com/proxy-season-updates/heads-up-for-the-2021-proxy-seasonfocus-on-diversity-disclosure/ ("For the 2021 proxy season thus far, shareholder proponents have submitted more than 60 proposals on diversity, racial justice and human capital issues more broadly, including proposals asking companies to prepare a diversity and inclusion report.").

${ }^{21}$ See Martijn Cremers, Jon Fulkerson \& Timothy B. Riley, Challenging the Conventional Wisdom on Active Management: A Review of the Past 20 Years of Academic Literature on Actively Managed Mutual Funds, 75 Fin. ANALYSTS J. 8, 21 (2019).

${ }^{22}$ Mark Carhart, On Persistence in Mutual Fund Performance, 52 J. Fin. 57, 57 (1997) (finding that the empirical evidence did "not support the existence of skilled or informed mutual fund portfolio managers"); see also Michael Jensen, The Performance of Mutual Funds in the Period 1945-1964, 23 J. FIN. 389, 415 (1968).

${ }^{23}$ William Sharpe, The Arithmetic of Active Management, 47 Fin. AnAlysts J. 7, 7 (1991).

${ }^{24}$ See Carhart, supra note 22, at 72.

${ }^{25}$ Eugene Fama \& Kenneth French, Luck Versus Skill in the Cross-Section of Mutual Fund Performance, 65 J. FIN. 1915, 1916 (2010). 
Buffett won a famous bet siding with indexers over hedge funds - at least those charging particularly high fees. ${ }^{26}$ Multiple editions of best-selling books continue to showcase dueling philosophies in academia: University of Pennsylvania finance professor Jeremy Siegel has repeatedly shown that buy-and-hold works, ${ }^{27}$ while Princeton University finance professor Burton Malkiel continues to release new editions of the book that legitimized indexing as a strategy. ${ }^{28}$

But changes in shareholder demographics during the past two decades, combined with increased competition and lower fees, produced a new strand of research challenging these conventional views. For instance, there is evidence that the average active fund does outperform an equivalent index; ${ }^{29}$ some top-performance records do persist; ${ }^{30}$ and a sizable cohort of managers with particular traits demonstrate skill that covers their fees. ${ }^{31}$ As University of Notre Dame finance professor Martijn Cremers suggests in his comprehensive review of contemporary research, among those traits are conviction and patience. ${ }^{32}$ Those are the defining traits of QSs.

Concerning particular investor performance, many different ratings exist such as Morningstar, Lipper, Zacks, TheStreet.com and Standard \& Poor's. ${ }^{33}$ These organizations segment investors into numerous categories

${ }^{26}$ In 2008, Buffett bet a hedge fund manager the S\&P 500 would, over the ensuing ten years, outperform, after fees, any hedge fund portfolio the manager cared to assemble. See BufFETT \& CUNNINGHAM, supra note 2, at 180-183. The manager assembled a fund of funds, a configuration charging multiple layers of high fees. During the first three years, the $\mathrm{S} \& \mathrm{P}$ lagged the fund, but by bet's end, the S\&P won. If many took from the bet the lesson that indexers are always superior to non-indexed investing, that is a mistake. The primary point was to stress that ordinary individuals are almost certainly better off, given the risks and fees, of staking their savings in index funds rather than entrusting it to high-cost hedge funds.

${ }^{27}$ See JeREMY J. Siegel, STOCKS FOR THE LONG Run 220 (5th ed. 2014); see also LouIS ENGEL \& HENRY R. HeCHT, HOW TO BUY STOCKS 125 (8th ed. 1994).

${ }^{28}$ See Burton G. Malkiel, A Random Walk Down Wall Street 257 (12th ed. 2019).

${ }^{29}$ Jonathan B. Berk \& Jules H. van Binsbergen, Measuring Skill in the Mutual Fund Industry, 118 J. FIN. ECON. 1, 17 (2015); Jonathan B. Berk \& Jules H. van Binsbergen, Mutual Funds in Equilibrium, 9 ANN. REv. FIN. ECON. 147, 162-64 (2017); Hyunglae Jeon, Jangkoo Kang \& Changjun Lee, Precision About Manager Skill, Mutual Fund Flows, and Performance Persistence, 40 N. AM. J. Econ. FIN. 222, 236 (2017).

${ }^{30}$ See Nicolas Bollen \& Jeffrey Busse, Short-term Persistence in Mutual Fund Performance, 18 REV. Fin. STUD. 569, 571 (2004); Robert Kosowski, Allan Timmermann, Russ Wermers \& Hal White, Can Mutual Fund "Stars" Really Pick Stocks? New Evidence from a Bootstrap Analysis, 61 J. FIN. 2551, 2593 (2006).

${ }^{31}$ Yakov Amihud \& Ruslan Goyenko, Mutual Fund's $R^{2}$ as Predictor of Performance, 26 Rev. Fin. STUd. 667, 680 (2013); Martijn Cremers \& Antti Petajisto, How Active is Your Fund Manager? A New Measure that Predicts Performance, 22 REV. Fin. STUD. 3329, 3332 (2009).

${ }^{32}$ Martijn Cremers \& Ankur Pareek, Patient Capital Outperformance: The Investment Skill of High Active Share Managers Who Trade Infrequently, 122 J. FIn. ECON. 288, 289 (2016). ${ }^{33}$ See e.g., Ratings, S\&P GLOBAL, https://disclosure.spglobal.com/ratings/en/regulatory/ratings-actions (last visited Sept. 11, 2021); Best Investments, MORNINGSTAR, https://www.morningstar.com/best-investments 
and subcategories such as sector (energy, technology etc.), style (value or growth), size (large, mid-cap, small), or time (a spectrum from one to 20 years). ${ }^{34}$ Such lists include frequent references to many QSs identified as such in Part II, including such household names as Capital Group, Fidelity, Franklin Templeton, and T. Rowe Price. ${ }^{35}$

\section{QS Attractor Performance}

It also appears to be the case that the companies in which QSs invest the most tend to outperform as well. For instance, QSI's database ranks a large sample $(\mathrm{n}=2070)$ of large companies according to their propensity to attract a high density of QS. First, we constructed a hypothetical portfolio of the QSDR top 20, equally weighted, and assumed invested from January 2014 through July 2021. That portfolio, whose names appear in Table I.1, generated a $17.27 \%$ (CAGR, with dividends reinvested) compared to $14.18 \%$ for the Vanguard 500 Index Investor.

\begin{tabular}{|l|l|}
\hline Roper Technologies, Inc. & AvalonBay Communities, Inc. \\
Selective Insurance Group, Inc. & Cincinnati Financial Corporation \\
AptarGroup, Inc. & General Dynamics Corporation \\
Amphenol Corporation & Lockheed Martin Corporation \\
Dolby Laboratories & Balchem Corporation \\
Bright Horizons Family Solutions Inc. & Gartner, Inc. \\
BlackRock, Inc. & Jack Henry \& Associates, Inc. \\
West Pharmaceutical Services, Inc. & News Corporation \\
Stryker Corporation & Digital Realty Trust, Inc. \\
Public Storage & Sensient Technologies \\
& Corporation \\
\hline
\end{tabular}

Table I.2: The QSI-20

Second, we compared two portfolios over the QSDR study period (2014-2018): one comprised of the 25 companies attracting the highest density of QSs and the other of the 25 attracting the lowest density of QS. The high QS density portfolio outperformed the low QS density portfolio in each of those five years. ${ }^{36}$

visited Sept 11, 2021); Zacks Rank, ZACKS https://www.zacks.com/stocks/zacks-rank (last visited Sept. 11, 2021); Lippers Leaders, LIPPERS

http://www.lipperleaders.com/QuickInfo.aspx?pid=Investors (last visited Sept 11, 2021);

Top Rated, THESTREETS, https://www.thestreet.com/topics/mutual-funds/top-rated-mutualfunds (last visited Sept. 11, 2021).

${ }^{34}$ See, e.g., Sector/Industry Research, S\&P GlobAL (last visited Sept. 11, 2021), https://www.spglobal.com/ratings/en/sector/corporates/corporate-sector.

${ }^{35}$ See infra text accompanying notes 52-54.

${ }^{36}$ Performance is measured as the cumulative return, or total change in the price of the investment expressed as a percentage, on daily unadjusted historical closing prices from the first trading day in 2014 through the last trading day of 2018. 


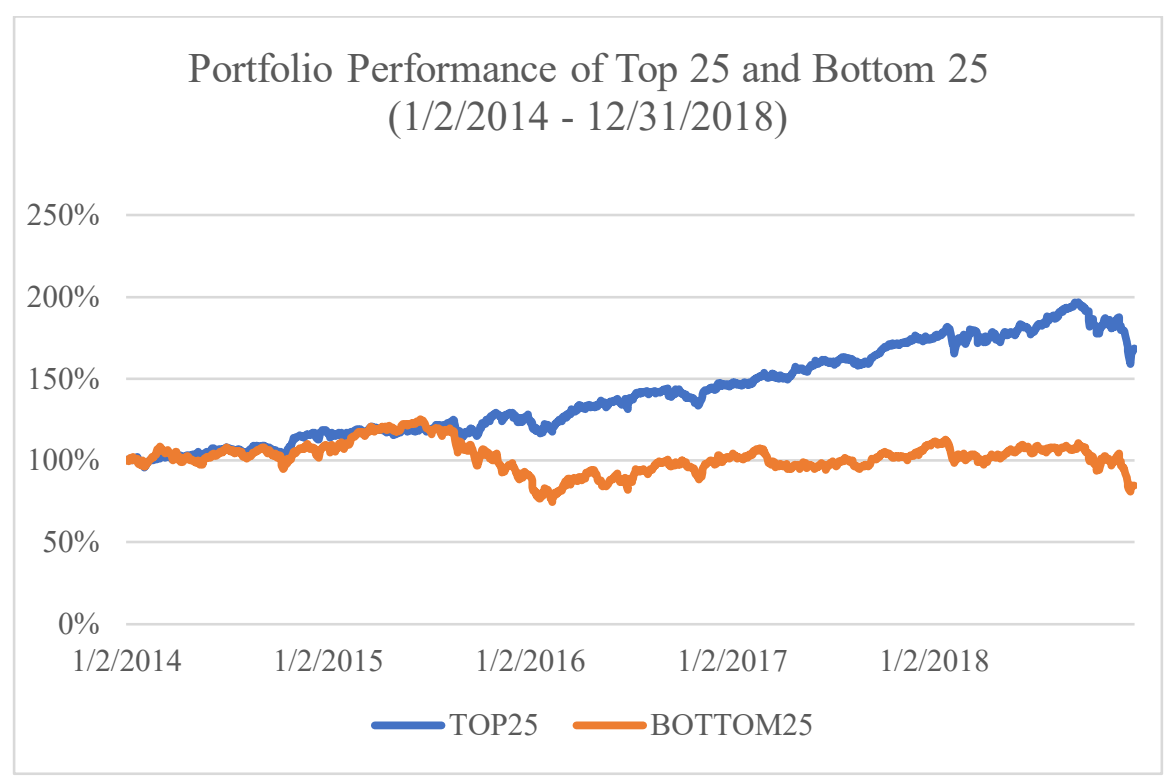

Third, we compared the relative performance of the top 69 in QS density on that list. Those with higher QS density tend to outperform those with lower, true even for longer periods. Consider the performance distribution of QS attractors over the 10-year period from 2010 through mid2020. For comparison, during that period, the cumulative return of the S\&P 500 was $181.9 \%$ and of the Russell $3000180.73 \%$.

In the following chart, such performance places both indices in the 100-200\% performance band (red bar). Of the top 69 QS attractors, sixty percent (41) outperformed while forty percent (28) underperformed. A hypothetical portfolio only with the top 69 QS attractors, each company given equal weights, outperformed the S\&P 500 by approximately $200 \%$. 


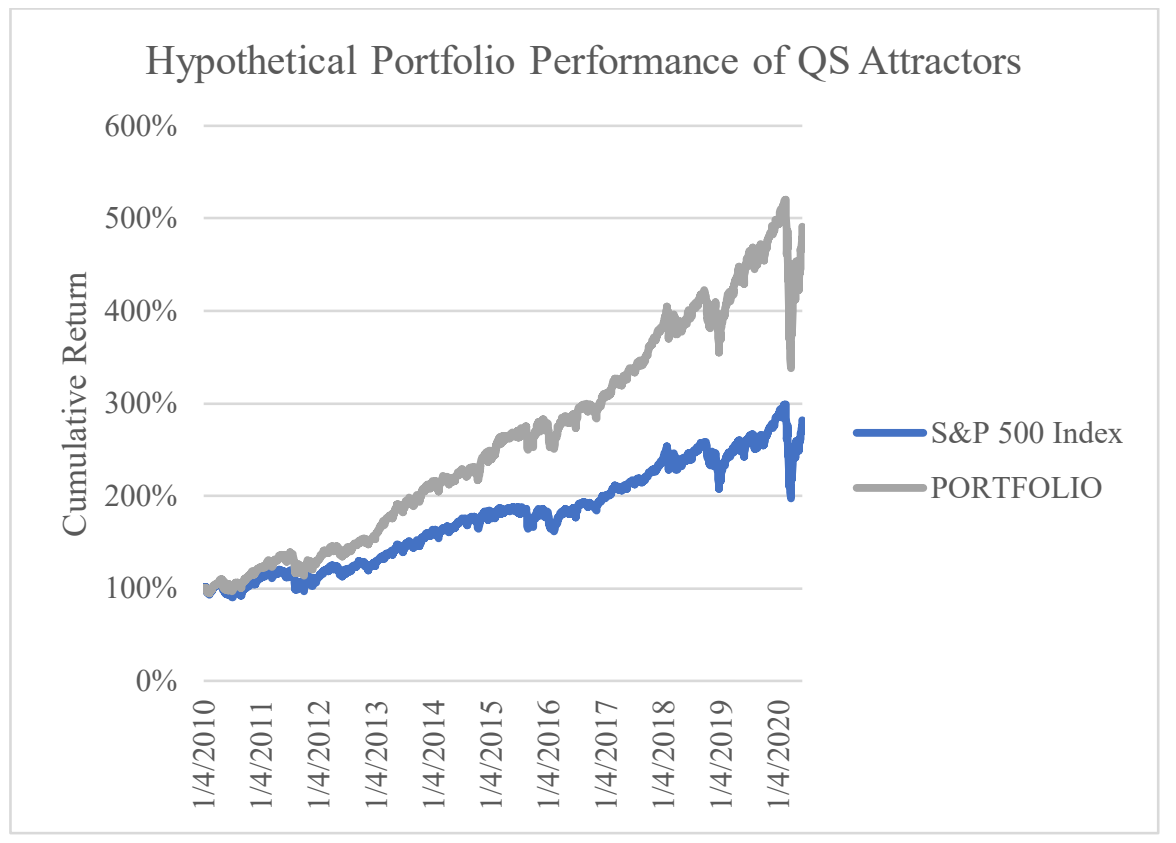

We recognize that this is an extremely limited sample and aim to conduct further testing. Meanwhile, however, the results accord with anecdotal evidence and can be explained on rational grounds. ${ }^{37}$ So why might companies with higher densities of QSs perform better than rivals with lower-quality shareholder bases? Superior economics and related performance would certainly attract such shareholders, so that high QS density is a consequence rather than a cause of such a correlation.

But it also seems plausible that the existence of a high density of QSs confers a variety of competitive advantages on corporations that help explain such superiority. For instance, QSs give managers longer time horizons to execute on strategy than transients; cast more informed shareholder votes than indexers that may add value; and pursue engagement with managers that is more productive and patient than activists, including providing a brain trust to draw upon for board service and consultation. ${ }^{38}$

\section{IDENTIFYING QSS AND THEIR ATTRACTORS}

In order to segment shareholders into these cohorts, it is necessary to apply both quantitative and qualitative analysis. While elements of judgment and assumptions are required, they are supported by the data. We

\footnotetext{
${ }^{37}$ See Martijn Cremers \& Ankur Pareek, Patient Capital Outperformance: The Investment Skill of High Active Share Managers Who Trade Infrequently, 122 J. OF FIN. ECON. 290, 304 (2016) (providing anecdotal information about investors who would qualify as QSs, and the comparative success of their investment strategies).

${ }^{38}$ See Cunningham, Quality Shareholders, supra note 8, at 25-27, 35, \&42.
} 
are reminded of the quip of noted quality management expert, W. Edwards Deming: "Without data, you are just another person with an opinion." 39

The adage attributed to John Maynard Keynes is also apt: "it is better to be approximately right than precisely wrong." ${ }^{\prime 4}$ This wisdom applies to any attempt to identify the QSs from among today's vast universe of institutional investors. Reliable selections depend on both objective criteria and subjective calls. The following is a summary of the approaches used in this research.

The primary selection criteria for this research are as follows: (1) QSs are shareholders that historically, over a multi-year period, have exhibited a consistent behavior of investing in high concentrations and for long holding periods; and (2) companies whose shareholder base is comprised of a high relative density of such shareholders.

Creating criteria to quantify shareholder cohorts raises challenges, like between what's short- and long-term and what's a diversified versus concentrated portfolio. While there are QSs under the tightest definitions of long-term and concentrated - say average holding periods of 8 years and no more than 20 stocks - today's investment universe is so prone to both trading and indexing that the pool tails off quickly. To some, plausible criteria for quality might be as little as a 2-year holding period and 200 or fewer stocks.

Some large financial institutions might be classified in one category but have multiple funds within them better classified in another. For example, Neuberger Berman as a firm in aggregate shows an index level of diversification yet offers many investors a selection of funds with managers who certainly count as QSs. ${ }^{41}$ Each fund within a family may warrant separate evaluation.

Also warranting separate evaluation are shareholders not required to publicly disclose their positions, unlike large institutions. These are individuals or small firms who shun the ubiquitous mutual funds in favor of selecting their own portfolio. They are clearly not indexers, though the exact distribution as transient versus QSs is hard to determine and may vary with different companies. One thing is clear: despite the rise of institutional equity

\footnotetext{
${ }^{39}$ Milo Jones \& Phillipe Silzerbahn, A Brave New World of Data, Forbes (Sept 18, 2021 6:04 PM) https://www.forbes.com/sites/silberzahnjones/2016/03/15/without-an-opinionyoure-just-another-person-with-data/?sh=41c0bd8699fc.

${ }^{40}$ See Hans Nilsson, It is better to be roughly right than precisely wrong, European Council for an Energy Efficient Economy, https://www.eceee.org/all-news/columns/it-is-better-tobe-roughly-right-than-precisely-wrong/ (last visited Oct. 31, 2021).

${ }^{41}$ Neuberger Berman Small Cap Growth Fund, NEUBERGER BERMAN, https://www.nb.com/en/us/products/mutual-funds/small-cap-growth-fund?nbmi=0954 (last visited Sept. 19, 2021) (showing a fund with high percentage of portfolio turnover); Neuberger Berman Intrinsic Value Fund, NEUBERGER BERMAN, https://www.nb.com/en/us/products/mutual-funds/intrinsic-value-fund?nbmi=1075 (last visited Sept. 19, 2021) (showing a fund with a lower-than-average percentage of portfolio turnover).
} 
ownership in recent decades, individuals and families still own one-third of corporate equity $-\mathrm{a}$ formidable cohort.

Some shareholders are QSs to one company while being another's indexer or transient: some shareholders may have a huge stake in one favored company held forever while the rest of the portfolio is either indexed or traded rapidly. For instance, First Manhattan is undoubtedly a QS of Berkshire Hathaway (at least $25 \%$ of its recent portfolio, since 1966) but not, say, a QS of Hostess Brands (it recently bought and sold a small stake within 3 quarters). ${ }^{42}$ Likewise, even Numeric, an exquisite transient, has $2.5 \%$ of its portfolio in Facebook held since its 2013 IPO. ${ }^{43}$

There are many ways to segment the shareholder universe to distinguish quality shareholders from the rest. Detailed in what follows are a dozen different techniques QSI has applied. Other databases and researchers may apply different tests and, depending on whether the research is proprietary or purely academic, may keep results confidential or publicize them.

All provide reliable inputs and rankings of a large number of institutional shareholders that file periodic portfolio reports with the SEC. Each database differs slightly in the covered population, the criteria applied, and the resulting classification scheme. This variety provides a menu for interested constituents to choose from to meet varying objectives.

For an academic example, Professor Bushee's academic database classifies investors into dedicated, transient and quasi-indexer, based on the combination of average holding periods and overall concentration level. ${ }^{44} \mathrm{In}$ effect, "dedicated" is the functional equivalent of QS. For a proprietary example, EQX also maintains the EQX database ranking investors by average relative holding periods and concentration levels, as well as the companies that attract them in high density. ${ }^{45}$

Other databases may focus on one or the other but not both. An example focused on concentration is the active share measure of Professors Cremers and Pareek, focused exclusively on concentration. ${ }^{46}$ Measuring

${ }^{42}$ First Manhattan Company Top $13 F$ Holdings, WhaLeWisdom, https://whalewisdom.com/filer/first-manhattan-co\#tabholdings_tab_link (last visited Sept. 17, 2021); Hostess Brands Inc A Owner History, FORMTHIRTEEN, https://formthirteen.com/securities/44109J106-hostess-brands-inc-a/history (last visited Sept. 17, 2021).

${ }^{43}$ Numeric Investors, Holdings Report (Form 13F) (Feb. 5, 2014); Man Group PLC, Holdings Report (Form 13F) (Aug. 16, 2021); Acquisition of Numeric by Man Group, MAN GROUP, https://www.man.com/acquisition-of-numeric (last visited Sept. 26, 2021) (showing that Numeric's holdings are filed under Man Group's 13F after Man Group Acquired Numeric in 2014).

${ }^{44}$ Brian Bushee, Identifying and Attracting the "Right" Investors: Evidence on the Behavior of Institutional Investors, 16 J. APPLIED. CORP. FIN. 28, 29 (2004).

${ }^{45}$ EQX, https://www.eqxse.com (last visited Sept. 8, 2021)

${ }^{46}$ See Martijn Cremers \& Ankur Pareek, Patient Capital Outperformance: The Investment Skill of High Active Share Managers Who Trade Infrequently, 122 J. FIN. ECON. 288, 29192 (2016). 
portfolio construction on a $0-1$ scale from pure index to pure concentration, active share has become a prominent metric to distinguish between purely passive asset managers and true stock pickers. ${ }^{47}$

It's helpful to use multiple research methods as no single metric can incontestably identify the cohort of QSs, given the judgments necessary in defining both duration and concentration as well as the varying sources available to segment shareholders along these lines. Accordingly, the QSI has employed many different methods-and continues to do so. The following is a survey and summary. Despite the variety, however, or perhaps due to it, there is remarkable overlap in the populations that the various methods yield. Accordingly, taken together, there does seem to be a discrete population of QSs that warrant study.

Surveys. One way to identify QSs, in general or at particular companies, is to survey leading investors. A similar method for identifying companies that succeed in attracting quality shareholders would survey investor relations professionals with analogous knowledge. The latter is an obvious winner for companies undertaking such an examination, whose inhouse staff is an excellent starting point.

The survey approach is endorsed in several prominent writings by and about outstanding investors, heavily oriented toward QSs. Examples include the celebrated 1984 Buffett article, The Superinvestors of Grahamand-Doddsville, and a 2005 sequel by Columbia University law professor Louis Lowenstein - along with a comment on the latter by Seth Klarman of Baupost Group, as well as numerous other books profiling outstanding investors. ${ }^{48}$ Such research yields the exemplars shown in Table II.1.

\begin{tabular}{|l|l|l|}
\hline Brave Warrior & Phil Fisher & Ruane Cunniff \\
Chieftain & Glenn Greenberg & Lou Simpson \\
Davis Selected Advisers & Grinnell College & Southeastern \\
First Eagle & J. M. Keynes & Tweedy Browne \\
First Manhattan & Charles Munger & Ralph Wanger \\
& Thomas Rowe Price & \\
\hline
\end{tabular}

Table II.1: QSs in Literature/Surveys

Berkshire Based. Given Warren Buffett's successful 50-year effort to attract QSs to Berkshire Hathaway, that company's shareholder list is a

${ }^{47} I d$; Investopedia, https://www.investopedia.com/articles/mutualfund/07/active-share.asp (last visited Sept. 17 2021).

${ }^{48}$ See Warren Buffett, The Superinvestors of Graham-and-Doddsville, HERMES, May 1985, at; Louis Lowenstein, Searching for Rational Investors in a Perfect Storm, 30 J. CORP. L. 539, 542-43 (2005); Seth A. Klarman, A Response to Lowenstein's Searching for Rational Investors in A Perfect Storm, 30 J. CORP. L. 561, 565 (2005); Bruce N. Greenwald, et al., VALUE INVESTING: From GRAHAM to BufFETT AND BEYOND 159, 211-24 (2001); see Allen C. Benello, Michael van Biema \& Tobias E. CARlisle, Concentrated Investing: STRATEGIES OF THE WORLD'S GREATEST CONCENTRATED VALUE INVESTORS 109-11 (2016); John Train, Money Masters of OUR Time 306 (2000). 
good place to find QSs. Start with the most concentrated Berkshire shareholders - there are at least 250 with more than $5 \%$ of their portfolio staked in the company, almost all of which have held the stock for decades. ${ }^{49}$

To make the search manageable and meaningful, select an appropriate sample or investment size, such as the 20 with the largest stakes or all those whose stakes exceed $\$ 250$ million. Examine their portfolios to identify other companies they concentrate in for long periods. Finally, examine those companies to identify other concentrated long-term shareholders. The result will be a credible group of both QSs and companies who attract them.

Examples of concentrated and substantial long-term Berkshire shareholders appear in Table II.2. Some other companies in which such Berkshire shareholders hold substantial long-term stakes are presented in Table II.3.

\begin{tabular}{|l|l|l|}
\hline Akre Capital & Everett Harris & Lourd Capital \\
Arlington Value & First Manhattan & Markel \\
Check Capital & Gardner Russo & Mar Vista \\
Consulta & Giverny Capital & Ruane Cunniff \\
Cortland Advisers & Global Endowment & Wedgewood Partners \\
Davis Selected Advisers & Greylin Investment & Weitz Investment \\
Douglass Winthrop & Kovitz & \\
Eagle Capital & Lee Danner \& Bass & \\
\hline
\end{tabular}

Table II.2: QSs of Berkshire Hathaway

\begin{tabular}{|l|l|l|}
\hline Abbott Labs & Credit Acceptance & Markel \\
Accenture & Danaher & Nestlé \\
Alphabet (Google) & Fairfax Financial & O'Reilly Automotive \\
Amazon & Johnson \& Johnson & Unilever \\
CarMax & Liberty Media & Wells Fargo \\
\hline
\end{tabular}

Table II.3: Other Investees of Berkshire Hathaway QSS

Existing Empirical Research. An additional resource is published empirical research. The methods can be adapted to suit particular companies, by features such as size or industry. Such research rarely lists particular shareholders by type, rather analyzing aggregate data to address broader questions. But there are exceptions, such as a Table II.4 of both QSs and transients in recent research about their different effects on given company

${ }^{49}$ See Quality Shareholders Initiative, Quality Shareholder Density Ranking (on file with the author and the QSI). 
risk profiles and market pricing. ${ }^{50}$ The following chart presents each type alphabetically.

\begin{tabular}{|l|l|}
\hline Among Top Quality & Among Top Transients \\
\hline Berkshire Hathaway & AIM \\
Capital Research \& Management & Investors Research \\
Jennison Associates & Janus \\
Fidelity Management \& Research & Putnam \\
Harris Associates (Oakmark Funds) & Marsico \\
State Farm & Oppenheimer \\
Southeastern Asset Management & UBS Warburg \\
Wellington & \\
\hline
\end{tabular}

Table II.4: QSs and Transients in Empirical Research

Cremers and Pareek created a 13F-based data set of all institutional investors dating to 1980, presenting, quarter-by-quarter, each shareholder's concentration (measured as deviation from the index, with the index equal to 0.0 ) and average holding period. ${ }^{51}$ In this massive data base, the cutoff for the top quintiles were 0.9 for concentration and 2.0 years for holding periods. ${ }^{52}$

From the top quartile of both-excluding foundations and private equity funds holding one or a few stocks - one doing this analysis should choose a relevant time period, such as the most recent five-years, omit duplicate names, and rank the remaining names by frequency of quarters making the list. This process yielded a total of 195 names, a rich vein of QSs. There was substantial overlap in this cohort with that identified using the other methods. Selected additional names appear in Table II.5 (alphabetically):

\begin{tabular}{|l|l|l|}
\hline Allen Holding & First Pacific & Timucuan \\
Bislett Mgmt. & Flood Gable & W. H. Reaves \\
Dane Falb Stone & Kahn Brothers & Wallace Capital \\
D.F. Dent & Sleep, Zakaria & Water Street \\
Fenimore & Southeastern & Westport \\
\hline
\end{tabular}

${ }^{50}$ See Paul Borochin \& Jie Yang, The Effects of Institutional Investor Objectives on Firm Valuation and Governance, J. FIN. ECON. 171, 175 (2017). The table highlighted the various QSs by portfolio size.

${ }^{51}$ Cremers \& Pareek, supra note 37, at 289.

52 Id. at 290 . The median concentration level is $79 \%$, with the authors classifying those below $60 \%$ as closet indexers. The median holding period is 1.166 years (14 months), with the bottom quintile breakpoint being .483 (7 months). Holding periods have been fairly stable over time, though increasing in recent years. Those with concentration scores above .96 are usually associated with special purposes, such as foundations whose portfolios are dominated by a single stock (Hershey Trust, Hewlett Foundation, Lilly Endowment); companies with large permanent stakes in publicly traded subsidiaries (Loews Corporation, Moody National Bank); and private equity firms with such transitional stakes (Apollo, Ares, Bain Capital, Thomas H. Lee Partners, General Atlantic, Pacific Financial). 


\section{\begin{tabular}{|l|l|l}
\hline Fiduciary Mgmt. & Speece, Thorson & Wintergreen Advisers
\end{tabular} \\ Table II.5: QSs Derived from Cremers-Pareek Data}

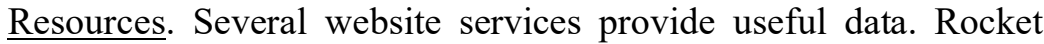
Financial digests quarterly updated $13 \mathrm{~F}$ filings. ${ }^{53}$ The site presents shareholder lists and investor portfolios in columns of data that can be sorted in a variety of ways and/or downloaded to spreadsheets for further manipulation, including calculating concentration. The site tabulates quarterly filings over time to enable calculating holding periods as well. ${ }^{54}$

The FloatSpec website was made available to Initiative researchers during its incubation and before its developers sold it to PJT Partners. Upon entering company or fund names, the site presents brief profiles along with rankings, such as fund turnover and certain categories of shareholder type. ${ }^{55}$ One extract ranked shareholders by a combination of their quartile rankings in terms of turnover and concentration. There was substantial overlap in this cohort with that identified using both the Berkshire method and the previously discussed method. Selected additional names appear in Table II.6 (alphabetically):

\begin{tabular}{|l|l|l|}
\hline Aristotle & Burgundy & Lee, Danner \& Bass \\
Atlanta & Douglass Winthrop & London Co. of VA \\
Barrow Hanley & Fairholme & Mar Vista \\
Beck, Mack \& Oliver & Franklin Mutual & Sprucegrove \\
Broad Run & Greenbrier & Tweedy Browne \\
Brown Brothers & Jackson National & \\
Harriman & & \\
\hline
\end{tabular}

Table II.6: QSs Derived from FloatSpec Data

IHS Markit maintains a rich database of shareholders and their investees. ${ }^{56}$ It is broad in scope, scooping up not only $13 \mathrm{~F}$ data but data from multiple other reliable sources. ${ }^{57}$ Using the database, we selected for investment managers with the lowest portfolio turnover as classified by the site and a concentration by ownership of 100 or fewer names. That resulted in a total of just 65 accounts, with the following 15 investing at least $\$ 1$ billion in equities.

\begin{tabular}{|l|l|l|}
\hline Alpine & Focused Investors & Marshfield Associates \\
\hline
\end{tabular}

53 Rocket Financial News and Filings 13F, Rocket FinANCIAL, http://www.rocketfinancial.com (last visited Sept. 25, 2021).

${ }^{54} \mathrm{Id}$.

55 See Christopher Friend \& Peter Heye, Do you know your Investors?, Medium (Jan. 8, 2018), https://medium.com/fintech-sandbox-the-weekly/do-you-know-your-investorsee08bbc8740f.

56 See Institutional ownership data: Quantitative research results, HIS MARKIT 1, 1 (Jun. 23, 2021), https://ihsmarkit.com/research-analysis/institutional-ownership-data-quantitativeresearch-results.html.

${ }^{57}$ See id. 


\begin{tabular}{|l|l|l|}
\hline Cacti & FPR Partners & McDonald Capital \\
Cantillon & Gardner Russo \& Gardner & Saratoga Research \\
Check Capital & Gillespie Robinson \& Grim & Schwerin Boyle \\
Compass Capital & Loews Corp. & Standard General \\
\hline
\end{tabular}

Table II.7A: QSs Derived from IHS Data

Trading Data. To proxy companies boasting patient shareholders, consider data relating either share trading volume to shares outstanding or dollar trading volume to market capitalization. We did the latter using S\&P Capital IQ data. ${ }^{58}$ We ran it for both smaller groups such as the S\&P 500, larger groupings such as the Russell 3000, and even larger universes encompassing substantially all publicly traded companies. We examined results on different timelines, one, three, and five years.

These are the 40 or so companies from the S\&P 500 with the lowest share turnover for the one-year period ending with the third quarter of 2018. These appear in Table II.7 (in order down the columns then across the rows).

\begin{tabular}{|l|l|l|}
\hline Berkshire Hathaway & Charles Schwab & Rollins \\
Alphabet (Google) & Stryker & Fortive \\
BlackRock & Northrop Grumman & Accenture \\
Johnson \& Johnson & Wells Fargo & Ecolab \\
The Coca-Cola Co. & American Express & General Dynamics \\
Walmart & Union Pacific & Marsh \& McLennan \\
Eli Lilly & Exxon Mobil & PPG Industries \\
Pfizer & 3M Company & Lockheed Martin \\
Abbott Labs & Roper Technologies & Bristol-Myers Squibb \\
Visa & Oracle Corporation & Microsoft \\
PNC Financial & JPMorgan Chase & Cisco Systems \\
Air Products & PepsiCo & Danaher \\
Procter \& Gamble & UnitedHealth & Intuit Inc. \\
\hline
\end{tabular}

Table II.7: QSs Derived from Trading Data (S\&P 500)

From among the Russell $3000,{ }^{59}$ Table II.8 presents selected names appeared in the top quintile (in order, down the columns and across the rows):

\begin{tabular}{|l|l|l|}
\hline Seaboard Corporation & Enstar & Graham Holdings \\
VICI Properties & Fairfax Financial & Liberty Global \\
Erie Indemnity & Markel & Alleghany \\
Brookfield Property & Constellation & Cimpress \\
& Software & \\
\hline
\end{tabular}

${ }^{58}$ See Ownership, S\&P GLOBAL,

https://www.marketplace.spglobal.com/en/datasets/ownership-(20) (last visited Sep. 20, 2021).

${ }^{59}$ See Membership list: Russell US Indexes, FTSE RUSSELL, https://content.ftserussell.com/sites/default/files/ru3000_membershiplist_20210628.pdf (last visited Sep. 21, 2020). 


\section{Table II.8: QSs Derived from Trading Data (Russell 3000)}

Empirical Data Analytics. In empirical research of this Initiative, we identified those institutional investors with the highest conviction in their positions and greatest patience, using a multi-factor ranking model, and identified some of the companies in which that cohort most often invested. We examined the 20F filings of institutional investors registered/operating in the U.S. and/or Canada which made quarterly reporting during all quarters from 2014 to 2018 , had a minimum \$1.1B AUM, ${ }^{60}$ and a majority of whose investments were in corporate equity. We removed avowed indexers, activists, and private equity.

Concerning conviction, the model analyzed such factors as: (1) the percentage weight of a stock in the portfolio; (2) relative concentration levels of the portfolio; (3) average voting power of the portfolio in the companies of the stocks it holds; (4) number of stocks in the portfolio with significant ownership ( $>0.1 \%$ of market cap); and (5) total number of stocks in the portfolio. Relative patience was probed by such factors as: (1) the portfolio's gross traded dollar-value compared to its AUM and (2) the rate and magnitude of change of a portfolio's constituents, calculated by taking the periodic standard deviation and overall standard deviation of stocks in a portfolio.

The top 20 QSs are presented in Table II.9 (in order, down columns and across rows):

\begin{tabular}{|l|l|l|}
\hline Berkshire Hathaway & Blue Harbour & Lyrical \\
Gates Foundation & Baker Brothers & Viking Global \\
State Farm Auto Ins. & Temasek Holdings & Capital Research Global \\
Baupost Group & Socpia Capital & Matrix Capital \\
Fiduciary Management & Lone Pine Capital & Stockbridge Partners \\
Southeastern & Kensico Capital & Glenview Capital \\
& Cantillon Capital & Irdian Asset Management \\
\hline
\end{tabular}

Table II.9: QSs Derived from QSI Empirical Analysis

Among portfolio positions representing at least $2 \%$ of each such QS's portfolio, 300 different stocks appeared. Of these, 20 appeared thrice or more as listed below and 38 appeared twice. Table II.10 presents a selection of those:

\footnotetext{
${ }^{60}$ While AUM data were not explicitly given, we defined an equation to compute the quarterly capital invested by each $13 \mathrm{~F}$ filer. Using the manager's identification number and stock holdings information, we aggregated quarterly holdings (shares owned multiplied by stock price) of each manager to compute quarterly AUM. To manage the data, at some cost in size skewing, only managers with average annual AUM (sum of quarterly AUM in a specific year divided by 4 quarters) exceeding $\$ 1$ billion were retained.
} 


\begin{tabular}{|l|l|l|}
\hline Twice (A Sampling) & $\underline{\text { Thrice }}$ & $\underline{\text { Four Times }}$ \\
\hline Abbott Labs & Allergan & Alibaba \\
Accenture & Anthem & Thermo Fisher \\
Autodesk & Booking Holdings & United Health \\
Berkshire Hathaway & Broadcom & $\underline{\text { Five Times }}$ \\
DowDuPont & Coca Cola & Amazon \\
Ecolab & Constellation Brands & Visa \\
ExxonMobil & Ebay & $\underline{\text { Six Times }}$ \\
FedEx & Intel & Facebook \\
Investors Bank & Mastercard & Microsoft \\
Liberty Media & Netflix & $\underline{\text { Nine Times }}$ \\
United Technologies & S\&P Global & \\
Walmart & TransDigm & \\
\hline
\end{tabular}

Table II.10: Common Investees of QSS

We also ranked a large sampling (2,070) of companies based on the extent to which their institutional investor base exhibits the traits of QSs, in terms of time-horizon and concentration, called the QS Density Ranking (QSDR). The QSDR is a proxy of the degree to which companies attract a high density of QSs. It can be used to understand which corporate policies and practices are associated with a high density of QS.

The QSDR can also be used to position companies boasting ownership by a particular QS in the context of the broader QS cohort. For instance, consider relating the foregoing list of companies in which the top 20 QSs tend to invest to the QSDR. All eight held four or more times are in the top half of the QSDR; among those held thrice nearly half (5/11) are in the top quarter (Allergan is not in the QSDR); and 64\% (7/11) are in the top quarter. In the random sampling of those represented twice, 58\% (7/12) are in the top quarter while $75 \%$ (9/12) are in the top half. Such figures suggest that when leading QSs invest significantly in a particular company, it is likely that a larger cohort of QS accompanies them.

$$
* * * * *
$$

We continue to add data points in our effort to identify QSs and the companies that attract them. Results vary across databases and methods, naturally, but there is remarkable overlap in most cases that yields a fairly reliable picture of the shareholders that make up this cohort and the companies they prefer. Appendix A presents an aggregation of some of the leading names of QSs and their investees.

\section{POLICIES AND PRACTICES}

QSI is investigating numerous strategies of shareholder engagement that might attract QSs. Concerning specific corporate policies or practices, 
we related publicly available data on various company practices to the QS density ranking of 2,070 companies based on their relative proportion of QSs (the "QSDR").

Specifically, focus is on the percentage of companies following (or not following) a given practice that appear high (or low) in the QSDR. For example, no association can be asserted if companies following (or not following) a given practice are evenly or haphazardly distributed across the 2,070 companies in the QSDR; but if the practice group members skew mostly towards the high (say half are in the top decile) or low end of the pool, such an association can be asserted.

We have tested a dozen levers and report the results in what follows. The levers are clustered logically around four major themes in contemporary literature on corporate governance and related topics. These are corporate purpose, corporate culture, corporate governance, corporate boards and corporate reality.

Corporate purpose, a voguish topic in corporate law scholarship of recent years, sparked by the Business Roundtable statement and the rise of ESG - both of which are reassessed here in light of the views QSs. ${ }^{61}$ In particular, QSs embrace both the BRT and ESG ideas, but largely because they are conventional rather than accord with the more radical fanfare and rhetoric that has blanketed popular discourse.

Corporate culture is also in fashion among corporate law scholars, stoked by a rising preoccupation with compliance and regulatory oversight. ${ }^{62}$ QSs are generally less enthusiastic about this development, tending to disfavor command and control cultures in favor of trust-based cultures characterized by decentralization and autonomy. Lessons here counsel against zealotry around compliance cultures, as trust trumps it.

Corporate governance remains topic after bursting onto the corporate law professor agenda in the 1980s, and it continues to bend towards rigid formulaic and universal mandates rather than flexible, tailored firm-specific provisions for which corporate law became famous generations ago. ${ }^{63}$ QSs favor the latter and for good reason: there has always been doubt about whether "good governance" so defined translates into superior corporate performance. ${ }^{64}$ Recent scholarship, moreover, challenges the

\footnotetext{
${ }^{61}$ See Lawrence A. Cunningham, Opinion: Here's evidence that putting customers and employees first turn out to be profitable for a company's stockholders too, MARKETWATCH (Oct. 14, 2020, 8:12 AM), https://www.marketwatch.com/story/heres-evidence-that-puttingcustomers-and-employees-first-turns-out-to-be-profitable-for-a-companys-stockholders-too2020-10-14?mod=lawrence-a.-cunningham_seemore; see Lawrence A. Cunningham, Opinion: These savvy investors were ESG-friendly long before it was fashionable, MARKETWATCH (Mar. 5, 2021, 2:51 PM), https://www.marketwatch.com/story/qualityshareholders-were-esg-friendly-long-before-it-was-fashionable11614800744?mod=lawrence-a.-cunningham.

${ }^{62}$ See Bryce Tingle, What Do we Really Know About Corporate Governance? A Review of the Empirical Research Since 2000, 59 CANADIAN Bus. L. J. 292, 293 (2018).

${ }^{63}$ See Sanjai Bhagat, Brian Bolton \& Roberta Romano, The Promise and Peril of Corporate Governance Indices, 108 COLUM. L. REv. 1803, 1863 (2008).

${ }^{64} \mathrm{See}$ Frankenreiter, et al., supra note 14 (manuscript at 55).
} 
empirical basis for the status quo's preference for prescription. ${ }^{65}$ The QSI contributions may therefore be particularly fruitful in this area.

Within corporate governance, a sub-set of important topics focuses on the board of directors, particularly their relative ownership and diversity. QSs value all three, it turns out, though somewhat differently than many. For instance, many call for directors to own a little bit of stock which is often given to them as a grant or through an option. ${ }^{66}$ QSs prefer large ownership stakes bought with the directors' own cash. ${ }^{67}$ On diversity, it has become the trend in recent years to push for racial and gender diversity on boards, including through statutes in California and disclose-or-explain rules on NASDAQ. ${ }^{68}$ QSs may or may not support such mandates, but there is evidence that they have supported more substantial results through volition rather than compulsion. ${ }^{69}$

Finally, unlike the foregoing, are a collection of off the beaten path points that QSs regard as central yet mainstream discussion has neglected or muted. First up is capital allocation, competitive advantages, shareholder communications, and long CEO tenures.

\section{A. Corporate Purpose $e^{70}$}

In 2019, the Business Roundtable, an elite lobbying group of U.S. executives, adopted a statement of corporate purpose that some say puts the interests of workers and communities above those of shareholders. ${ }^{71}$ In this view, the Roundtable rejected shareholder-centered statements of corporate purpose, such as that of economist Milton Friedman, who wrote in 1970 that

${ }^{65} \mathrm{Id}$.

${ }^{66}$ See, e.g., Stephen M. Bainbridge \& M. Todd Henderson, Boards-R-Us:

Reconceptualizing Corporate Boards, 66 STAN. L. REV. 1051, 1073 (2014).

${ }^{67}$ See CUNNINGHAM, QuALITY SHAREHOLDERS, supra note 8, at 56.

${ }^{68}$ S.B. 826, 2018 Leg., Reg. Sess. (Cal. 2018); NASDAQ, Rule 5606 (2021).

${ }^{69}$ See CunNingham, QuALITY SHAREHOLDERS, supra note 8, at 137.

70 This section comes from Cunningham's Quality Investing columns in MarketWatch of October 14, 2020 and March 3, 2021. This section comes from Cunningham's Quality Investing columns in MarketWatch of October 14, 2020 and March 3, 2021. See generally Lawrence A. Cunningham, Opinion: These Savvy Investors Were ESG-Friendly Long Before It Was Fashionable, MARKETWATCH (Mar. 3, 2011, 2:45 PM),

https://www.marketwatch.com/story/quality-shareholders-were-esg-friendly-long-before-itwas-fashionable-11614800744 (providing background information on ESG and their influence in attracting QSs); Lawrence A. Cunningham, Opinion: S\&P 500 Corporate Boards Lack Diversity, but These Top Companies Are Leading Change - and the Stock Market Rewards Them, MARKETWATCH (Oct. 24, 2020, 9:38 AM),

https://www.marketwatch.com/story/sp-500-corporate-boards-lack-diversity-but-these-topcompanies-are-leading-change-and-the-stock-market-rewards-them-2020-10-23 (providing background information on QSs and how diversity affects and intersects with corporations).

${ }^{71}$ Business Roundtable Redefines the Purpose of a Corporation to Promote 'an Economy That Serves All Americans', Bus. RoundTABle (Aug. 19, 2019), https://www.businessroundtable.org/business-roundtable-redefines-the-purpose-of-acorporation-to-promote-an-economy-that-serves-all-americans [https://perma.cc/RJW6ZBHW]. 
the social responsibility of business is to increase its profits for shareholders. $^{72}$

Heated debate has followed. ${ }^{73}$ Champions of corporate social responsibility herald the Roundtable's statement, while critics claim it would impose public obligations on the private sector. ${ }^{74}$ Skeptics warn that having business leaders answering to many different constituents will impair corporate accountability. ${ }^{75}$

"Yet there is a good case that there is less at stake than meets the eye" - and not because the exercise was for show, but because it states a reliable formula for corporate success. ${ }^{76}$ And there is evidence that QSs tend to agree with the Business Roundtable's statement. ${ }^{77}$

Debate arises from the order of priorities in the Roundtable's statement of corporate purpose: customers, employees, suppliers, and communities all come before stockholders, who are at the end. ${ }^{78}$ But while this may sound inverted, the truth is profits for shareholders are increased by

\footnotetext{
${ }^{72}$ Milton Friedman, A Friedman Doctrine-- the Social Responsibility of Business Is to Increase Its Profits, N.Y. TiMES (Sept. 13, 1970), https://www.nytimes.com/1970/09/13/archives/a-friedman-doctrine-the-socialresponsibility-of-business-is-to.html [https://perma.cc/5GYL-XA8L].

${ }^{73}$ See generally Edward B. Rock, For Whom Is the Corporation Managed in 2020? The Debate Over Corporate Purpose, 76 Bus. LAw. 363, 363-65 (2021) (providing an overview of "a high-profile public debate [that] is taking place over one of the oldest questions in corporate law, namely, '[f]or whom is the corporation managed?"').

${ }^{74}$ See, e.g., Margaret Blair, Two Years After the Business Roundtable Statement: Pointing in the Right Direction, Promarket (Sept. 13, 2021), https://promarket.org/2021/09/13/business-roundtable-statement-right-directioncorporations-behaving-badly/ (arguing the Business Roundtable statement was a baby step in the right direction because it has shifted dialogue to take into account stakeholders instead of just shareholders but that it has not yet realized its goal); Nir Kossovsky, Opinion: Fulfilling the Promise of the Business Roundtable's Statement on Corporate Purpose, CORPORATE SECRETARY (Aug. 30, 2021), https://www.corporatesecretary.com/articles/boardroom/32698/opinion-fulfilling-promisebusiness-roundtable\%E2\%80\%99s-statement-corporate (arguing that companies overpromised in their adoptions of the Business Roundtable statement).

75 See, e.g., Adina Holzman \& Lisa Silverman, Statement on the Purpose of a Corporation: 733 Days Later, JD SuPRA (Aug. 20, 2021), https://www.jdsupra.com/legalnews/statementon-the-purpose-of-a-1577930/ (explaining the various stakeholders and their positions relative to the BR statement); see also Leo E. Strine, Jr., The Dangers of Denial: The Need for a Clear-Eyed Understanding of the Power and Accountability Structure Established by the Delaware General Corporation Law, Univ. of Pa. Inst. for Law and Econ. Rsch. Paper No. 15-08, 6-7, 9 (2015).

${ }^{76}$ Lucian Bebchuk \& Roberto Tallarita, Was the Business Roundtable Statement Mostly for Show?, HARV. L. SCH. F. ON CORP. GovernANCE (August 19, 2020), https://corpgov.law.harvard.edu/2020/08/18/was-the-business-roundtable-statement-mostlyfor-show-2-evidence-from-corporate-governance-guidelines/; Lawrence A. Cunningham, Opinion: Here's Evidence that Putting Customers and Employees First Turns Out to Be Profitable for a Company's Stockholders Too, MarketWatch (Oct. 14, 2020, 8:12 PM), https://www.marketwatch.com/story/heres-evidence-that-putting-customers-and-employeesfirst-turns-out-to-be-profitable-for-a-companys-stockholders-too-2020-10-14.

${ }^{77}$ Cunningham, supra note 76.

${ }^{78} \mathrm{Id}$.
} 
catering to customers, rewarding employees, partnering with suppliers, and being good corporate citizens. ${ }^{79}$

Nor is the Roundtable's statement novel. ${ }^{80}$ In fact, it is almost a carbon-copy of the revered credo of Johnson \& Johnson, in place since 1943. ${ }^{81}$ Throughout that time, J\&J has taken this mission statement seriously, if not flawlessly, tending to the interests of all constituents, and delivering shareholder profits as a result. ${ }^{82}$

As for what shareholders might think, the companies signing the Roundtable's statement are strong attractors of QSs. ${ }^{83}$ The QSDR includes most of the $\sim 180$ Roundtable statement's signatories. ${ }^{84}$ Among those signatories, the vast majority rank in the top half for QS density, and onefourth in the top decile. ${ }^{85}$ In other words, QSs are drawn disproportionately to the companies whose CEOs signed the statement. ${ }^{86}$

Nor is the Business Roundtable statement novel or unique. ${ }^{87}$ For many years, the Drucker Institute has advocated similar principles, associated with its namesake, management professor Peter Drucker. ${ }^{88}$ These are statistically rigorous measures of customer satisfaction, employee engagement, innovation, social responsibility, and financial strength. ${ }^{89}$ The Drucker Institute annually applies these principles to rank the companies in the S\&P $500 . .^{90}$ There is a strong association between companies ranked highly by the Drucker Institute and QS density. ${ }^{91}$

Why might QSs agree with the Business Roundtable's mission statement and the Drucker Institute's principles? For one, given the longterm horizons of QSs, as compared to the short-term view of transient shareholders, what is good for a corporation's employees, customers,

${ }^{79} I d$.

${ }^{80}$ Cunningham, supra note 76.

${ }^{81}$ Id.; Our Credo, JOHNSON \& JoHnSON, https://www.jnj.com/credo/ (last visited Sept. 26, 2021).

${ }^{82}$ See David Collins, A Lesson in Social Responsibility: Corporate Response to the 1980s Tylenol Tragedies (Sept. 27, 2002); Cunningham, supra note 76.

${ }^{83}$ Cunningham, supra note 76.

${ }^{84}$ Lawrence A. Cunningham, Initiative on Quality Shareholder Highlights, C-LEAF OCCASIONAL PAPER SERIES (Fall 2020).

${ }^{85}$ Of the 183 signatories, 135 are on the QS Density Ranking. Among those, one-third are in the top $10 \%$ of the QSDR, $55 \%$ are in the top quarter, and $81 \%$ are in the top half. See id. ${ }^{86} \mathrm{Id}$.

${ }^{87}$ Principles Underlying the Drucker Institute's Company Rankings, DRUCKER INSTITUTE, https://www.drucker.institute/principles-underlying-the-drucker-institutes-companyrankings/ (last visted Sept. 26, 2021).

${ }^{88} I d$.

${ }^{89} I d$.

${ }^{90} I d$.

${ }^{91}$ Among the Drucker 2018 list of the top 150, the QS Density Ranking contained 141. Of these, $28 \%$ of the Drucker 150 are in the top 10\% of the QS Density Ranking; 54\% are in the top quarter; and $84 \%$ are in the top half. See CunNINGHAM, supra note 84 (citing Rick Wartzman \& Kelly Tang, The Business Roundtable's Model of Capitalism Does Pay Off, WALL ST. J. (October 27, 2019), https://www.wsj.com/articles/the-business-roundtablesmodel-of-capitalism-does-pay-off-11572228120). 
suppliers, and communities tends to be particularly good for long-term, highquality shareholders. ${ }^{92}$

Second, given the focused investment approach of QSs, as compared to the all-market gauge of indexers, flexibility is essential, and the Roundtable's statement and Drucker principles are appealingly flexible. They let individual companies express their mission their own way and are general enough that directors can meet their legal duties that, unchanged, require promoting the best interests of the corporation and its shareholders.

Toward one end of the spectrum, consider the philosophy of signatory Stanley Bergman, Chairman and CEO of Henry Schein, a company that tops the charts for QS density and has outperformed for shareholders regularly since going public in $1995 .^{93}$ constituents:

In a 2015 interview, Bergman put forth this view of corporate

"For the suppliers, the customers and the [employee] teams to work together, you need capital, because it's a business. We are very clear with Wall Street: Henry Schein does not exist for the investors. Having said that, we promise the investors a good rate of return and we deliver on those expectations."94

Toward the other end is the philosophy of an American business legend, the late Roberto Goizueta, who headed The Coca-Cola Company from 1981-1997. ${ }^{95} \mathrm{He}$ often stated his view of corporate purpose as "the maximization of shareholder value." ${ }^{.96}$ On Goizueta's watch, Coca-Cola was regularly ranked by Fortune Magazine among America's most-admired companies. ${ }^{97}$ It delivered outsized shareholder returns by nurturing a business that catered to customers' tastes, developed employees, and protected communities. ${ }^{98}$ The company was also deft at attracting QSs, most famously Warren Buffett. ${ }^{99}$

Buffett exemplifies the middle ground. He is well-known for investing in companies that are "owner-oriented," and takes that approach as CEO of Berkshire Hathaway. ${ }^{100}$ Yet he recognizes the need for balancing the interests of shareowners with employees and other constituents. Consider Buffett's 1985 discussion of a wrenching decision to close an ailing textile mill:

92 Bus. RoundTABLE, supra note 71.

${ }^{93}$ Cunningham, Quality SHAREHOlders, supra note 8, at 57-58.

${ }^{94} \mathrm{Id}$. at 58 .

${ }^{95}$ Id.; Roberto Crispulo Goizueta, EnCYClOPAEDia BRITANNICA (Nov. 14, 2020), https://www.britannica.com/biography/Roberto-Crispulo-Goizueta.

${ }^{96}$ CunNingham, Quality SHAREHOLDERS, supra note 8, at 58.

${ }^{97}$ Edward A. Robinson, America's Most Admired Companies, Fortune (Mar. 3, 1997), https://money.cnn.com/magazines/fortune/fortune_archive/1997/03/03/222760/index.htm.

${ }^{98}$ CunNingham, Quality SHAREHOLDERS, supra note 8, at 58.

${ }^{99}$ See BuffetT \& CunNingham, The EsSAYS OF WARREN BufFETT, supra note 2, at 4.

${ }^{100}$ CUNNINGHAM, QuAlity SHAREHOLDERS, supra note 8, at 56. 
I won't close down businesses of sub-normal profitability merely to add a fraction of a point to our corporate rate of return. However, I also feel it inappropriate for even an exceptionally profitable company to fund an operation once it appears to have unending losses in prospect. Adam Smith would disagree with my first proposition, and Karl Marx would disagree with my second; the middle ground is the only position that leaves me comfortable. ${ }^{101}$

That comfortable middle ground is often reflected in the mission statements of many companies that top lists of both QS density and profitability. ${ }^{102}$ When companies focus on their constituents in these ways, shareholder profits should follow. QSs should be attracted, creating a virtuous circle that may explain the association between high QS density and superior corporate performance. While it may seem that the Business Roundtable now repudiates Milton Friedman's views, QSs signal that there is far greater overlap than the heated debate suggests.

The same is true when it comes to ESG, fashionable principles addressing matters of environmental, social, and governance significance. ${ }^{103}$ QSs have been prospering by using such principles for decades, long before the United Nations popularized them in 2005. ${ }^{104}$ The QSI compared two recent ESG rankings, by Barron 's ${ }^{105}$ and Investors' Business Daily, ${ }^{106}$ with the QSDR.

The ESG and QS data correlate: the vast majority ( $80 \%$ or more) of high-ranking ESG companies also rank in the top half for QS density. ${ }^{107}$ Topping the Barron's/IBD lists of ESG companies that also rank high for QS are newer and older companies alike: younger companies such as Nvidia (1993) and Salesforce (1999), and venerable titans such as Colgate-

\footnotetext{
101 See Buffett \& Cunningham, The EsSAys of WARren Buffett, supra note 2, 55-56.

102 See Cunningham, QuAlity Shareholders, supra note 8, at 57, 61. For example, consider these three mission statements that focus on customers, employees, and communities: Nike ("To bring inspiration and innovation to every athlete in the world. If you have a body, you are an athlete."); Harley-Davidson ("We fulfill dreams of personal freedom."); Ford Motor Co. ("To make our cars better, our employees happier and our planet a better place to be.").

${ }^{103}$ George Kell, The Remarkable Rise of ESG, Forbes (Jul. 11, 2018), https://www.forbes.com/sites/georgkell/2018/07/11/the-remarkable-rise-ofesg/?sh=74d647721695.

${ }^{104} I d$.; Quality Shareholder Initiative, supra note 49.

105 Evie Liu, The 100 Most Sustainable Companies, Reranked by Social Factors, BARRON's (June 26, 2020), https://www.barrons.com/articles/these-companies-rank-best-on-socialcriteriaand-could-reward-investors-51593215993.

106 IBD Staff, 50 Best ESG Companies: Top Stocks for Environmental, Social and Governance Values, Invs. Bus. DAILy (Aug. 18, 2021), https://www.investors.com/news/esg-companies-list-best-esg-stocks-environmental-socialgovernance-values.

${ }^{107}$ Specifically, among the 46 IBD winners on the QSDR, 23\% are in the top 10\%, half are in the top quarter, and 83\% (38/46) in the top half; among the 47 Barron's winners on the QSDR, 20\% are in the top 10\%, 50\% in the top quarter, and $80 \%$ in the top half. See CUNNINGHAM, QUALITY SHAREHOLDER, supra note 104.
} 
Palmolive (1806), Procter \& Gamble (1837), Kimberly Clark (1872), Kellogg (1906), Clorox (1913), Best Buy (1966), and Texas Instruments (1951). ${ }^{108}$

History suggests that QSs are attracted to ESG principles because both reflect long-term company-specific thinking. ${ }^{109}$ Unlike past social movements, moreover, ESG keeps shareholder interests at the core of corporate mission, as documented in important research by Professors Lund and Pollman. ${ }^{110}$

To put ESG in historical context, consider the debates over corporate purpose in the 1930s, following the Great Depression. One side, led by Columbia University law professor Adolf Berle, argued that corporate directors must be accountable to shareholders; ${ }^{111}$ the other, led by Harvard University law professor Merrick Dodd, urged a corporate pursuit of social objectives. ${ }^{112}$

Both views went mainstream, as companies focused on shareholder profits while making substantial charitable donations. The accommodation remained uneasy, however, as some reformers, such as economist Howard Bowen, advocated greater corporate "social responsibility." 113

In the 1970s, debate reignited on corporate purpose. Economists, echoing Berle, favored shareholder primacy while critics, led by Ralph Nader, urged taming corporations to respond to public needs. ${ }^{114}$ The Naderites won many legislative milestones during the 1970s, from protecting consumers to the environment. ${ }^{115}$ But their assaults on corporate America went too far, it turned out, and an era focused solely on "shareholder value" followed. ${ }^{116}$

In the takeover fights of the 1980s, insurgents stressed "shareholder value," while embattled directors lobbied to consider "other constituencies," especially employees and communities. ${ }^{117}$ Yet by urging prioritizing such constituents, advocates again overplayed their hand: in the end, directors

\footnotetext{
${ }^{108}$ Liu, supra note 105; IBD Staff, supra note 106.

${ }^{109}$ Dorothy S. Lund \& Elizabeth Pollman, The Corporate Governance Machine, 121 Colum. L. REV. (forthcoming 2021).

${ }^{110} \mathrm{Id}$.

111 A.A. Berle, Jr., Corporate Powers as Powers in Trust, 44 HARV. L. REv. 1049, 1049 (1931).

${ }^{112}$ E. Merrick Dodd, Jr., For Whom Are Corporate Managers Trustees?, 45 HARV. L. REv. 1145,1148 (1932).

${ }^{113}$ Howard R. Bowen, Social Responsibilities of THE BusinesSMAN 4-5 (1953).

${ }^{114}$ RALPH NADER, ET AL, TAMING THE GIANT CORPORATION 119 (1976); Holly J. Gregory, Everything Old is New Again-Reconsidering the Social Purpose of the Corporation, HARV. L. SCH. F. ON CORP. GOVERNANCE (Mar. 12, 2019), https://corpgov.law.harvard.edu/2019/03/12/everything-old-is-new-again-reconsidering-thesocial-purpose-of-the-corporation/.

${ }^{115}$ Cunningham, supra note 76.

${ }^{116} \mathrm{Id}$.

117 See Brett H. McDonnell, Corporate Constituency Statutes and Employee Governance, 30 WM. Mitchell L. ReV. 1228 (2004).
} 
could legally incorporate interests of other constituencies but only if those rationally related to shareholder interests, which held priority. ${ }^{118}$

From the 1990s, critics again assailed shareholder primacy as irresponsible. ${ }^{119}$ Despite gaining some prominence, this movement likewise overshot its mark by advocating diverting corporate assets from shareholders to others. ${ }^{120}$

Still, these movements planted important seeds. For one, they revealed excesses of the status quo. As indicated in a 1987 Congressional report, obsession with stock prices arose, and with it pressure to put shortterm results over long-term gains. ${ }^{121}$ Boards started paying executives in corporate equity, riveting attention on stock price. ${ }^{122}$ Managers now publicized quarterly forecasts and hosted quarterly calls for investment analysts, stoking short-term pressure. ${ }^{123}$

Researchers in the early 2000s, meanwhile, began finding correlations between certain practices deemed "socially responsible" and corporate financial performance, in categories from employee relations and pollution control to product quality and community involvement. ${ }^{124}$

These dynamics set the stage in 2005 for the United Nations to issue its ESG principles. ${ }^{125}$ The U.N. said that "integrating ESG factors into corporate and investor decisionmaking was critical for the security of investments, prosperity, and growing markets." ${ }^{" 126}$ It unveiled its "Principles for Responsible Investment" at the New York Stock Exchange, citadel of shareholder primacy. ${ }^{127}$

Unlike their predecessors, these ESG principles stress factors that enhance long-term shareholder value, an approach that concurs with history, law, and practicalities. ${ }^{128}$ As a result, ESG went mainstream. ${ }^{129}$

From the 1980s to the early 2000s, socially responsible companies, such as Ben \& Jerry's Ice Cream (founded in 1978) or The Body Shop

\footnotetext{
118 See David G. Yosifon, The Law of Corporate Purpose, 10 Berkeley Bus. L. J. 181, 192 (2013).

${ }^{119}$ LAWRENCE E. Mitchell, CORPORATE IRRESPONSIBILITY: AMERICA's LATEST EXPORT (2001).

${ }^{120} I d$. at 36.

121 See Chairman of Subcomm. On Telecommunications, Consumer Protection, And Finance of H. Comm. on Energy and Commerce, 99Th Cong., Corporate TAKeOvers: Public Policy ImPlications for the ECONOMY AND CORPORATE GOVERNANCE 77 (Comm. Print 1986).

122 Lund, supra note 109, at 9.

${ }^{123}$ See id.at 9-10, 15.

${ }^{124}$ Mauricio Agudelo et al., A Literature Review of the History and Evolution of Corporate Social Responsibility, 4 INT'L J. CORP. SOC. RESP. 1, 10-12 (2019).

${ }^{125}$ Who Cares Wins Conference, Investing for Long-Term Value: Integrating Environmental, Social and Governance Value Drivers in Asset Management and Financial Research, at 1, 4 (Aug. 25, 2005).

${ }^{126}$ Lund, supra note 109, at 37.

${ }^{127} \mathrm{Id}$.

128 See id.

129 See id.
} 
(1976), stood out as unusual. ${ }^{130}$ Today, companies that fail to acknowledge ESG are outliers. ${ }^{131}$ QSs favor ESG's emphasis on businesses and strategies that are "sustainable," a fashionable word that QSs have been using for decades. ${ }^{132}$ While radical adaptations of ESG principles are destined to follow history into failure, it is likely to endure if proponents keep the movement mainstream. ${ }^{133}$ Similarly, despite prevailing cultures of control in corporate life, people may actually do better when they are trusted rather than controlled.

\section{B. Corporate Culture and Trust ${ }^{134}$}

For decades, American corporate culture has moved in the direction of command and control. ${ }^{135}$ Boards faced rising pressure for accountability, leading them to command corporate officers to install elaborate internal controls, information systems and compliance programs. ${ }^{136}$ While wellintentioned, such efforts dampen the bonds of trust employees up and down the ranks need to have. ${ }^{137}$

Over the same period, corporate governance moved toward prescribed mandates for all companies. ${ }^{138}$ Today all boards are expected to follow delineated protocols ordained "best practices," whether or not they are best for a particular company. ${ }^{139}$ Such uniformity diminishes the trust

\footnotetext{
${ }^{130}$ See Lewis D. Solomon, On the Frontier of Capitalism: Implementation of Humanomics by Modern Publicly Held Corporations: A Critical Assessment, 50 WASH. \& LEE L. REV. 1625, 1637-38, 1640 (1993).

${ }^{131}$ Cunningham, supra note 76.

${ }^{132} \mathrm{Id}$.

${ }^{133} I d$.

134 This section is adapted from Cunningham's Quality Investing columns in MarketWatch of December 19, 2020 and June 30, 2021, both of which draw upon LAWrENCE A. Cunningham \& Stephanie Cuba, Margin of Trust: The Berkshire Business Model (2020). See generally Lawrence A. Cunningham, Trust Is the Secret Sauce that Warren Buffett and Others Value Highly in Companies, MARKETWATCH (Dec. 19, 2020), https://www.marketwatch.com/story/trust-is-the-secret-sauce-in-companies-that-warrenbuffett-and-others-value-highly-2020-12-17; Lawrence A. Cunningham, Why High-Quality, Trustworthy Companies Have Beaten the S\&P 500 by 30\%-50\%, MARKETWATCH (Jun. 30, 2021), https://www.marketwatch.com/story/why-high-quality-trustworthy-companies-havebeaten-the-s-p-500-by-30-50-11625020379.

${ }^{135}$ See Melvin A. Eisenberg, The Board of Directors and Internal Control, 19 CARDOZo L. REv. 237, 240-44 (1997).

${ }^{136}$ See Lawrence A. Cunningham, The Appeal and Limits of Internal Controls to Fight Fraud, Terrorism, Other Ills, 29 J. CoRP. L. 267, 301-02 (2004); Stavros Gadinis \& Amelia Miazad, The Hidden Power of Compliance, 103 MinN. L. REv. 2135, 2147 (2019).

137 See Dennis Reina \& Michelle Reina, Trust and Betrayal in the WorkPlace: BuILDing EFFECTIVE RELATIONSHIPS IN YOUR ORGANIZATION 80-82 (3d ed. 2015).

${ }^{138}$ Eisenberg, supra note 135, at 240-44.

${ }^{139}$ See Sanjai Bhagat et al., The Promise and Peril of Corporate Governance Indices, 108 Colum. L. Rev. 1803, 1862 (2008); Roberta Romano, The Sarbanes Oxley Act and the Making of Quack Corporate Governance, 114 YALE L.J. 1521, 1523 (2004); Michal Barzuza, Noise Adopters in Corporate Governance, 2013 Colum. Bus. L. REV. 627, 663; Bryce Tingle, What Do We Really Know About Corporate Governance? A Review of the Empirical Research Since 2000, 59 CAN. Bus. L. J. 292, 323 (2017).
} 
that can form when directors and shareholders exchange views and make their own decisions based on the needs of the company. ${ }^{140}$

Countering this trend of control is a trust-based culture. ${ }^{141}$ A trustbased corporate culture relies on the assumption that businesses should be decentralized into the smallest possible units whose performance can usefully be measured to identify problems and opportunities. ${ }^{142}$ Hallmarks of a trust-based corporate culture therefore include autonomy and decentralization. ${ }^{143}$

Trust is a powerful motivator. ${ }^{144}$ Autonomy empowers employees to focus on tasks rather than on reporting compliance. Payoffs include more effective leadership, lower cost of administration, and other corporate efficiencies.

Warren Buffett's Berkshire Hathaway exemplifies this approach. ${ }^{145}$ It takes a famously hands-off approach to management, delegating all responsibility to the heads of its subsidiaries. ${ }^{146}$ The trust-based approach works because the most important quality Berkshire looks for in new managers and companies is trust - they pass up opportunities if they have a shred of doubt about trustworthiness. ${ }^{147}$

Accountability follows. Based on interviews of scores of Berkshire executives over the years, the consensus view was summed up in a pithy comment by Jim Weber, head of Brooks Running Company where he said he had never been given so much autonomy in his business career and had never felt so accountable and responsible. ${ }^{148}$

The tone of trust is set at the top and percolates throughout the organization in daily decisions, challenges, and crises, and the result constitutes the company's culture. ${ }^{149}$ Trust-based corporate cultures may be characterized as learning organizations where employees enjoy considerable autonomy and where small groups are allowed to experiment and then share knowledge across the company.

Such hallmarks continue to characterize a wide range of businesses today, especially insurance companies as well as diversified industrials. Insurance is a trust-based business, after all, where the product is the promise

\footnotetext{
${ }^{140}$ Cunningham, supra note 134.

141 See id. at 15.

${ }^{142}$ Lawrence A. Cunningham, Berkshire's Disintermediation: A Managerial Model for the Next Generation, 50 WAKE Forest L. Rev. 509, 510-11 (2015); Lawrence A. Cunningham, Berkshire's Blemishes: Lessons for Buffet's Successors, Peers, and Policy, 2016 Colum. Bus. L. Rev. 1, 1.

${ }^{143} I d$.

${ }^{144}$ See Margaret M. Blair \& Lynn A. Stout, Trust, Trustworthiness and the Behavioral Foundations of Corporate Law, 149 U. PA. L. REV. 1735, 1780 (2001).

${ }^{145}$ See David F. Larcker \& Brian Tayan, Berkshire Hathaway: The Role of Trust in Governance, STANFORD ClOSER LOOK SERIES (May 28, 2010), at 1-2.

${ }^{146}$ Id.

${ }^{147}$ Cunningham, supra note 134.

148 See Cunningham, BerkshiRe Beyond Buffett 188 (2014).

${ }^{149}$ See id. at 105.
} 
to pay money and its value is almost entirely in being trusted to pay. ${ }^{150}$ In the broader market, exemplars of trust-based cultures vary but tend to be united by core practices such as autonomy and decentralization. ${ }^{151}$

The Trust Across America (TAA) initiative has identified the most trustworthy U.S. public companies using objective and quantitative indicators including accounting conservativeness and financial stability, as well as a secondary screen of more subjective criteria such as employee reviews and news reports. ${ }^{152}$ Companies regarded as trustworthy also tend to rate highly in rankings of shareholder quality produced by the QSI, as well as the proprietary database of EQX, which we use to cross-check QSI data. ${ }^{153}$ TAA's assessment of the S\&P 500 SPX, $+0.75 \%$ in 2020 identified 51 companies, of which 49 are also included in the QSI rankings. Comparing the two, more than one-fourth of the top TAA companies are in the top decile of the QSI; two-thirds are in the top quarter, and all but two (92\%) are in the top half. ${ }^{154}$ Notably, both the TAA top 10 and the QSI Top 25 outperformed the S\&P 500 by $30 \%$ and $50 \%$, respectively, in recent five-year periods. ${ }^{155}$

While some investors focus solely on the bottom line and others only on signals of corporate virtue, QSs are holistic, considering the inherent relationship between trust and long-term value. ${ }^{156}$ Nebulous as the notion of trust in corporate culture might seem, it's a profitable as well as ethical value to probe. ${ }^{157}$ In the same spirit, contemporary commentary and policy has promoted uniformity in governance through rigid specification of practices. The QS research suggests that greater flexibility would be better, as discussed next.

\section{Governance Flexibility or Rigidity ${ }^{158}$}

\footnotetext{
${ }^{150}$ Among insurance companies touting trust-based cultures - and performance and shareholder followings to match — are Alleghany, W.C. Berkley, Erie Indemnity, Fairfax Holdings, and Markel. See Quality Shareholder Initiative, supra note 49.

151 These include Constellation Software, Danaher, Dover, Illinois Tool Works, Roper Technologies, and TransDigm Group. Id.

152 See Barbara B. Kimmel, Building Trust Into Investing (2020).

${ }^{153}$ Cunningham, supra note 134.

${ }^{154} I d$.

${ }^{155}$ A sampling of companies scoring high on both trust and quality includes Texas Instruments, the chip maker (whose QSs include: Alliance Bernstein, Bessemer Group, Capital World Investors, State Farm Mutual, and T. Rowe Price Group; Ecolab, the water treatment company (QSs include: Cantillon Capital, Clearbridge Investments, Franklin Resources, and the Gates Foundation); and Ball Corporation the world's largest manufacturer of recyclable containers (QSs include: Chilton Investment Co.; T. Rowe Price; Wellington Management Group and Winslow Capital Management). Id.

${ }^{156} I d$.

${ }^{157} I d$.

${ }^{158}$ Parts of this section are adapted from Cunningham's Quality Investing column in MarketWatch of August 12, 2021; Financial Post op-ed (with George Athanassakos) of December 15, 2020; and Quality Investing columns in MarketWatch of November 18, 2020 and November 11, 2020. Lawrence A. Cunningham, The ' $G$ ' in ESG is Getting a Big Shake-Up and It's a Win for Stock Investors, MARKETWATCH (Aug. 11, 2021, 7:18 AM),
} 
Conventional wisdom is that a litany of governance practices, called good, correlate with superior corporate performance. But the QSI has found reasons to quarrel with this conventional wisdom in several contexts and more recent scholarship has undermined much of the edifice supporting the conventional views.

Empirical research on corporate governance dates back about two decades to pioneering work by finance professors Gompers, Ishi, and Metrick. ${ }^{159}$ Using data created by the Investor Responsibility Research Center (IRRC, now part of Institutional Shareholder Services or ISS), an entire generation of researchers became convinced that there's a difference between "good corporate governance" and "bad corporate governance."160 Good governance increases "democratic" shareholder rights, like oneshare/one-vote, and bad governance increases "despotic" managerial power, like a CEO also chairing the board. Good governance reaps better returns for shareholders than bad governance, conventional wisdom and much scholarship held. ${ }^{161}$

But according to the new study by law professors Jens Frankenreiter, Cathy Hwang, Yaron Nili and Eric Talley (FHNT), this research contains many errors. ${ }^{162}$ Coders misinterpreted source material on some basic features $^{163}$, such as whether a company had dual class shares, a staggered board or supermajority voting. In a multi-year effort, these scholars have built an entirely new dataset they hand-coded from the governance provisions of nearly 3,000 public company charters. ${ }^{164}$ Comparing their

\footnotetext{
https://www.marketwatch.com/story/the-g-in-esg-is-being-shaken-up-in-a-new-way-thatshould-help-stock-investors-11628645743; George Athanassakos \& Lawrence A.

Cunningham, Pick One-Conformist Governance or Good Capital Allocation, FINANCIAL Post (Dec. 15, 2020), https://financialpost.com/opinion/opinion-pick-one-conformistgovernance-or-good-capital-allocation; Lawrence A. Cunningham, Active Managers See Value in These 3 Company Practices but Indexers Hate them. Who's Right?, MARKETWATCH (Nov. 28, 2020, 10:08 AM), https://www.marketwatch.com/story/indexersblast-these-3-corporate-decisions-but-they-actually-can-boost-a-companys-andshareholders-results-2020-11-19; Lawrence A. Cunningham, Companies Whose Board Members are Also Major Shareholders Typically Outperform. Here's How to Find Them, MARKETWATCH (Nov. 11, 2020, 12:58 PM), https://www.marketwatch.com/story/clickhere-on-a-companys-website-for-clues-about-how-the-stock-will-perform-2020-11-11. 159 Gompers et al., supra note 5, at 107.

${ }^{160}$ E.g., Jonathan M. Karpoff, Robert J. Schonlau \& Eric W. Wehrly, Do Takeover Defense Indices Measure Takeover Deterrence?, 30 REV. FIn. STUD. 2359 (2017); Melih Madanoglu \& Ersem Karadag, Corporate Governance Provisions and Firm Financial Performance, 28 InT'L J. ConTEMP. Hosp. MGMt. 1805 (2015); Lucian Bebchuk, Alma Cohen \& Allen Ferrell, What Matters in Corporate Governance?, 22 REv. FIN. STUD. 783 (2009); Miroslava Straska \& H. Gregory Waller, Antitakeover Provisions and Shareholder Wealth: A Survey of the Literature, 49 J. FIN. \& QUANT. ANALYSIS 933 (2014).

${ }^{161}$ Researchers built on the Gompers et al research to proliferate numerous variations to delineate good and bad governance using similar datasets. See Karpoff et al., supra note 160. Big advisors to large institutional investor advisors such as ISS and MSCI commercialized recommendations based on such data.

${ }^{162}$ Frankenreiter et al., supra note 14.

${ }^{163} I d$.

${ }^{164} I d$.
} 
findings with the original IRRC data and its offspring, FHNT report "alarming" errors in the original coding. ${ }^{165}$ Aggregate effects are dramatic, such as erasing most of any return premium to democratic compared to despotic companies.

Defenders of the status quo stress that the new research does not undermine the entire edifice, as much data and advice have been generated using other tools, such as relating executive compensation to corporate performance. ${ }^{166}$ But critics welcome the spotlight the new research shines on the often-obscure data behind the received wisdom in today's governance debates, from takeover defenses to shareholder voting methods. ${ }^{167}$

For investors, the new research highlights that it's unwise to rely blindly on assertions of what counts as good or bad governance from any source - proxy advisors, data analytics vendors, professional service firms or academics. All participants must probe the quality of the underlying datasets, particularly whether governance scores are based on these erroneous indexes. ${ }^{168}$

Scholars should be particularly attentive to the perceived causes of these longstanding errors. For one, proprietary services such as ISS and MSCI have incentives to maintain strict data control, selectively selling access for substantial premiums to commercial clients. ${ }^{169}$ For another, chief researchers in governance data analytics have been from fields such as finance, not law. The researchers encourage lawyers to dig into the data too-something the QSI is taking seriously, as reported in this Article.

In the context of received wisdom on good versus bad governance, we compared an important annual study of Canadian boards with a study of their company's corporate performance. The Canadian investment community tends to follow that of the U.S. closely, including on the conventional wisdom of what counts as good governance.

In the 2020 installment, researchers at the University of Toronto's Johnston Centre for Corporate Governance Innovation defined a set of boardroom best practices and then ranked companies based on their degree

\footnotetext{
${ }^{165} I d$.

${ }^{166}$ Approach Hyperbolic Claims About the New Corporate Governance Data with Skepticism, VALUEEDGE ADVISORS (Mar. 14, 2021), https://valueedgeadvisors.com/2021/03/14/approach-hyperbolic-claims-about-the-newcorporate-governance-data-with-skepticism.

167 John Jenkins, Corporate Governance: Back to the Drawing Board?, THE CORPORATE COUNSEL (Mar. 19, 2021), https://www.thecorporatecounsel.net/blog/2021/03/corporategovernance-back-to-the-drawing-board.html.

${ }^{168}$ It also pays to understand the provider's baseline for good governance. The literature traditionally references corporate performance or shareholder returns as the baselines, whereas today's providers may stress different priorities associated with such movements as impact investing, socially responsible investing or ESG investing. Cunningham, supra note 158.

169 States like Delaware, the leading charterer of corporations, charge hefty fees to obtain corporate charters and make them available in technologically primitive formats. The FHNT research team estimates the total cost of building a database from the Delaware charters alone would be half a million dollars. Frankenreiter, supra note 14, at 17-18.
} 
of conformity with it. ${ }^{170}$ They established four categories - board composition, director share ownership, shareholder rights, and disclosure and used 38 different indicators to rank $211 \mathrm{~S} \& \mathrm{P} / \mathrm{TSX}$ issuers. ${ }^{171}$

In a study of "value-investor CEOs," that is, CEOs who had the investing skills necessary to deploy the cash company cash to the best valuemaximizing opportunity, Professor Athanassakos identified an elite group of exceptional capital allocators, 41 Canadian and 167 American. ${ }^{172}$ The study ranked companies by their success in capital allocation and then compared portfolios comprised of those at the top versus the bottom. ${ }^{173}$ On average, the superior allocator portfolio outperformed the inferior one by 33 per cent in cumulative three-year returns over several recent decades. ${ }^{174}$

Overlaps in the data sets are revealing. Of the best 41 Canadian capital-allocating companies, 28 were also ranked in the University of Toronto governance study. ${ }^{175}$ Among the leading capital allocators, however, only four ranked in the top quarter of the governance rankings. ${ }^{176} \mathrm{By}$ contrast, some of the best capital allocators ranked lowest on the governance scale. ${ }^{177}$ In related research, the QSI found that the superior allocators ranked high in attracting QSs. ${ }^{178}$

\section{CEO and Chair}

Turning to governance, the $\mathrm{U}$ of $\mathrm{T}$ rankings give the highest marks for conforming to standardized practices, without probing to what extent, if at all, they may be expected to result in superior capital allocation or shareholder stewardship. ${ }^{179}$ For instance, the study credits companies that split the roles of chairman and CEO, but without recognizing that combining them remains both common and apparently effective at a large portion of public companies. ${ }^{180}$

\footnotetext{
${ }^{170}$ See David Milstead, Board Games 2020: How We Ranked Canada's Corporate Boards, Globe \& MAIL (Nov. 30, 2020).

171 See BOARD GAMES: 19 YEARS OF SHINING A SPOTLIGHT INTO CANADA'S BOARDROOMS, DAVID AND SHARON JOHNSTON CENTRE FOR CORPORATE GOVERNANCE INNOVATION, RotMAN SCHOOL OF MANAGEMENT, University of TORONTO, (Nov. 30, 2020).

172 See George Athanassakos, Do high quality shareholders gravitate to companies led by good asset allocator CEOs? Ben Graham Centre Blog (May 11, (2020)),

https://www.ivey.uwo.ca/bengrahaminvesting/blog/2020/05/do-high-quality-shareholdersgravitate-to-companies-led-by-good-asset-allocator-ceos/; See also George Athanassakos and Lawrence A. Cunningham, Pick one - conformist governance or good capital allocation, FINANCIAL POST (Dec. 15, 2020).

${ }^{173}$ See id.

${ }^{174}$ See id.

${ }^{175}$ See id. See also Milstead, supra note 170.

176 These are: Emera, TC Energy, Fortis and Telus. See Milstead, supra note 170.

177 These included CGI, Restaurant Brands, Rogers Communications, and Westshore Terminals. See id.

${ }^{178}$ See infra Section III.E.1.

${ }^{179}$ See Milstead, supra note 170.

${ }^{180}$ See Spencer StuART BoARd IndeX 18 (2020); id.
} 
Leading indexers and proxy advisers oppose combining the roles because boards appoint and oversee the CEO. ${ }^{181}$ Having one person wear both hats creates a conflict, they say. Yet many corporations thrive when led by an outstanding person serving as both chair and chief, while others have failed amid split roles-Enron is an example. ${ }^{182}$ After all, board chairs get only one vote, so it comes down to the capability of the other directors. Good ones neutralize such a conflict.

The data supports the view that context matters. About half the S\&P 500 companies split the functions while the other half combines them. ${ }^{183}$ Despite indexer complaints, QSs are as likely to own stakes in companies that split these functions as those that combine them, according to QSI data. They look past formal checklists to substantive details.

Corporate performance results show that there is no right or wrong answer, only "it depends." Among 20 best-performing companies over the past decade, the proportion with each practice matched the overall proportion of companies using it. ${ }^{184}$ In other words, these practices add or subtract value depending on context, especially the chief executive's identity and the board's caliber, even the shareholder makeup.

\section{Multiple share classes}

Likewise, the U of T study credits "one-share, one-vote" capital structures, thus penalizing dual-class companies, but without considering the particular history, reasons and context for the structure at different companies.

By convention, every corporate share has one vote; but in these setups, insiders often get more votes for their shares than outsiders, putting power in a controlling minority. Critics say that insulates controllers from accountability and market discipline. ${ }^{185}$ They lobbied unsuccessfully to

\footnotetext{
${ }^{181}$ E.g., Institutional Shareholder Service, Proxy Voting Guidelines 19-20 (2020).

${ }^{182}$ Lawrence A. Cunningham, The Secret Sauce of Corporate Leadership, WALL ST. J. (Jan. 25, 2015); See also generally Mariana Pargendler, The Corporate Governance Obsession, 42:2 THE J. OF CORP. L., 359, 383 (2016).

${ }^{183}$ Companies remain nearly evenly divided over the practice; among the S\&P 500, for instance, $55 \%$ splitting the functions and $45 \%$ combining them. See SPENCER STUART BOARD INDEX (2020) at 18. Our statistics are based on Spencer Stuart's 2018 data for the S\&P 500 showing that 229 split and 245 combine; of these, 216 and 234, respectively, appear in the QSDR. Of those splitting, $16 \%$ are in the top 10\%, $40 \%$ in the top quarter, and $89 \%$ in the top half; of those combining, $28 \%$ are in the top $10 \%, 57 \%$ in the top quarter, and $84 \%$ in the top half.

${ }^{184}$ See Philip van Doorn, These Are the 20 Best-performing Stocks of the Past Decade, MARKETWATCH (Dec. 28, 2019). https://www.marketwatch.com/story/these-are-the-20best-performing-stocks-of-the-past-decade-and-some-of-them-will-surprise-you-2019-1209.

185 See Lucian A. Bebchuk \& Kobi Kastiel, The Untenable Case for Perpetual Dual-Class Stock, 103 VA. L. REV. 585, 602 (2017).
} 
outlaw the practice, but in 2017 prevailed upon indexers, such as S\&P, to exclude newly listed dual class stock. ${ }^{186}$

Yet even after the index exclusion, dual class companies continued to go public, joining hundreds of others who have followed the practice for decades. ${ }^{187}$ These include such long-term stalwarts as Aflac, Berkshire Hathaway, Estee Lauder Companies and The New York Times Company, as well as contemporary starlets like Alphabet (Google), Facebook, and Snap. ${ }^{188}$ The practice is ideal for certain company types, especially those needing quality shareholders to support long-term businesses, such as spirits (Brown Forman), or those with valuable roots in families (Tootsie Roll Industries) or entrepreneurs (Nike). ${ }^{189}$

Terms also vary, from simple board seat allocations to complex control formulas. Some even protect outsiders against insider tyranny, such as at McCormick \& Co. and United Parcel Service. ${ }^{190}$ It's no wonder, yet again, that QSs are not averse to owning shares in dual class companies, according to QSI data.

In short, while corporate tradition provides shareholders with onevote-per-share, alternative shareholder voting rules abound. Examples include dual class structures giving different votes-per-share to different classes, as well as time-weighted voting, more votes to longer-held shares. ${ }^{191}$ QSs are attracted to many such companies, including those listed in Table III.1, which rank in the top quartile of QS density. The data suggest that QSs examine capital structures on a case-by-case basis rather than making blanket condemnations (or proclamations). ${ }^{192}$

\footnotetext{
${ }^{186}$ Council of Institutional Investors, Dual Class Discussion Draft: Investor as Owner Subcommittee of SEC Investor Advisory Committee 2 (2017); see also Amy Deen Westbrook and David A. Westbrook, Snapchat's Gift: Equity Culture in High-Tech Firms, 46 FLA. St. U. L. REV. 861, 866 (2019).

187 See Scott Hirst \& Kobi Kastiel, Corporate Governance by Index Exclusion, 99 B.U. L. REV. 1229, 1266, 69 (2019).

${ }^{188}$ Council of Institutional Investors, Dual Class Companies List 1-2, 5, 15-16 (2017).

${ }^{189}$ Cunningham, supra note 9, at 45; see also id at 2, 11, 16. See also Dorothy S. Lund, Nonvoting Shares and Efficient Corporate Governance, 71 STAN. L. REv. 697 (2019).

${ }^{190}$ See generally Council of Institutional Investors, Dual Class Companies List 10, 17 (2017) (voting structures that cap voting power after a given ownership level threshold help ensure powerful insider shareholders cannot dictate over smaller shareholders).

${ }^{191}$ See Lynne L. Dallas \& Jordan M. Barry, Long-Term Shareholders and Time-Phased Voting, 40 DEL. J. CORP. L. The importance of QSs warrants considering "quality voting"more votes to longer-held shares owned by concentrated shareholders. See Lynne L. Dallas \& Jordan M. Barry, Long-Term Shareholders and Time-Phased Voting, 40 DEL. J. CORP. L. 541, 564 (2016). See also Patrick Bolton \& Frederic Samama, Loyalty-Shares: Rewarding Long-term Investors, 25 J. APPLIED CORP. FIN. 86 (2013).

${ }^{192}$ Comparing the CII's list of 225 companies, supra note 188, with the QSDR, 135 companies appear on both lists. The data largely followed a random pattern, rather than being skewed, with $11 \%$ in the top $10 \%$; $30 \%$ in the top 25\%Q; and $64 \%$ appeared in the $50 \%$.
} 


\begin{tabular}{|l|l|l|}
\hline Aflac & Erie Indemnity & McCormick \& Co. \\
Berkshire Hathaway & Estee-Lauder Companies & Moog \\
Brown-Forman & John Wiley \& Sons & Nike \\
Constellation Brands & Expedia & Hershey \\
Discovery Comm. & Graham Holdings & New York Times Co. \\
DISH Network & Hyatt Hotels & United Parcel Service \\
\hline
\end{tabular}

Table III.1: Dual Class and QS Density

Empirical evidence on the effects of time-weighted voting is limited. ${ }^{193}$ Only a handful of U.S. companies currently maintain timeweighted voting: Aflac, Carlisle, J.M. Smucker, Quaker Chemical, and Synovus Financial. ${ }^{194} \mathrm{~A}$ few others once employed time-weighted voting but have since rescinded it: CenturyTel, Church \& Dwight, Cincinnati Milacron, Roper, and Shaw Group. ${ }^{195}$ Despite the small sample size, all five U.S. companies that have time-weighted voting rank high in attracting QSs. ${ }^{196}$

\section{Director Share Ownership}

The $\mathrm{U}$ of $\mathrm{T}$ ranking credits boards that require directors to own a certain amount of the company's stock, when it would obviously be preferable to credit directors who buy large stakes without being required to do so. ${ }^{197}$ Similarly, the rankings weight handling of stock options heavily in terms of hurdles, vesting periods, dilution - without crediting companies who simply avoid using them due to their questionable effects and contested accounting. ${ }^{198}$

\footnotetext{
${ }^{193}$ See David J. Berger, Steven Davidoff Solomon \& Aaron J. Benjamin, Tenure Voting and the U.S. Public Company, 72 Bus. L. 295, 307 (2017).

${ }^{194}$ Council of Institutional Investors, Dual Class Companies List 1, 3, 12, 15 (2017).

195 The Delaware Supreme Court upheld the validity of a charter amendment adopting timeweighted voting in Williams v. Geier, 671 A.2d 1368 (Del. 1996).

${ }^{196}$ Much as with the debate over dual class and the contrary QSI findings are the debate and findings concerning staggered board of director terms. Both debates reflect a similar substance versus form battle. At some companies, every director stands for election every year while at others only one-third do, each for three-year terms. Critics oppose such threeyear terms as impairing board accountability. See Cunningham, supra note 9, at 39. Yet a staggered board may enable a company to embrace a longer time horizon than one that can turn over completely in any year. Value arises from such binding commitments to long-term strategies. See K.J. Martijn Cremers, Simone M. Sepe, \& Saura Masconale, Is the Staggered Board Debate Really Settled?, 167 U. PA. L. Rev. OnLINE 9 (2019). These realities are reflected in historical company practices, which vary. Staggered boards are used at nearly half of Russell 3000 companies, although the figure among S\&P 500 companies has fallen to about 60, in response to indexer pressure in recent years. QSs grasp this point too: they invest just as much in companies with staggered boards as without them, according to the following data analysis. We compared the 61 companies among the S\&P 500 with staggered boards to the first 61 in alphabetical order that do not. We related each group of 61 to the QSDR. The data showed a very slight preference for unitary boards: among the top decile of QSDR companies, 8 had classified boards versus 22 unitary; among the top quarter of QSDR companies, 25 had classified boards versus 34 unitary; and among the top half were 52 and 53, indistinguishable.

197 Athanassakos \& Cunningham, supra note 172; Milstead, supra note 170.

198 Id.
} 
To QSs, director share ownership is a signal about stewardship: directors will act most like shareholders when they are shareholders; the higher the stakes, the more passionate the stewardship. The underlying logic can be seen by considering the field of venture capital, where the effects of a company's major shareholder-directors are clear.

The standard-bearer here is the legendary George Ohrstrom. Through his venture firm, Ohrstrom sagely guided the incubation of such durable companies as Carlisle, Dover and Roper Technologies. ${ }^{199}$ While no intelligent investor blindly follows others or simplistic formulas, its pays to watch what the Ohrstroms of the world do.

Beyond venture capital, the research indicates that among large public companies today, a high proportion of QSs correlates with superior corporate performance. In companies that lead the charts in both shareholder quality and performance, a common feature is at least one director with large long-term personal stakes. In addition to those mentioned in what follows, some examples appear in Table III.2. ${ }^{200}$

\begin{tabular}{|l|l|}
\hline Abbott Labs & General Dynamics \\
Aptar Group & Illinois Tool Works \\
AutoNation & Jack Henry \& Associates \\
Bright Horizons & O’Reilly Automotive \\
Cincinnati Financial & Public Storage \\
Credit Acceptance & Ross Stores \\
Danaher & Selective Insurance Group \\
Gartner Inc. & \\
\hline
\end{tabular}

Table III.2: Substantial Director-Owner QS Density

Some CEOs publicly attest to the value of such directors. One is Mike Jackson, CEO for more than twenty years at AutoNation. The company, owner of a network of car dealers, attracted an impressive list of quality shareholders over those decades. From among these, two joined the board, whom Jackson credits with vastly improved corporate performance. Each held $15-16 \%$ of the stock for more than a decade: investor Eddie Lampert tutored board colleagues on capital allocation and Michael Larson of the Gates Foundation counseled them on disciplined, patient long-term thinking. ${ }^{201}$

The board of Credit Acceptance Corporation, lender to sub-prime borrowers, boasts two quality shareholders: Scott Vassalluzzo, of Prescott

\footnotetext{
${ }^{199}$ See Lawrence A. Cunningham, Opinion: These 15 Companies are run in a Warren Buffet-like way, MARKETWATCH (Feb. 27, 2021).

${ }^{200}$ Director ownership rankings are based on data for director share ownership in WRDS's ISS Directors database, presenting 2019 data for S\&P 400, 500, and 600 companies. Director profiles were obtained from individual company websites and/or proxy statements. Featured companies are those whose board included at least one independent director with significant long-term holdings in the company (a QS), ranking in the top five percent of the QSDR, and outperforming indexes described in Section I.

${ }^{201}$ CunNingham, QuAlity SHAREHOLDERS, supra note 8, at 43.
} 
General Partners, which owns $10 \%$ of the stock, and Tom Tryforos, who teaches the fundamentals of traditional investing at Columbia Business School. ${ }^{202}$ CEO Brett Roberts attests to the enduring value of their board service, stressing in a shareholder letter how Tryforos's perspective as an investor helped managers appreciate that all corporate decisions must be tested in terms of a minimum return on capital. ${ }^{203}$

Many other companies adept at attracting quality shareholders have named some to their boards: Berkshire Hathaway in 2005 appointed Sandy Gottesman of First Manhattan, the company's largest shareholder after Warren Buffett since 1966; Constellation Software has since going public in 2006 benefited from the board service of Steve Scotchmer, a distinguished Canadian investor and owner of a large personal stake for decades; and for many years Enstar Group's board included Chuck Akre, a noted QS.

Through 2013 when The Washington Post Company sold its flagship newspaper, the company had since 1976 saved nearly one billion dollars in pension plan costs thanks to savvy investment advice given by the prominent investors Sandy Gottesman and Bill Ruane. ${ }^{204}$ Those mavens were suggested and introduced to the company by one of its earliest and revered QSs: Buffett. ${ }^{205}$ Another Washington Post veteran is Alan Spoon, of Polaris Partners, also a shareholder-oriented director adding value at such companies as Danaher, Fortive and IAC, and formerly Cable One. ${ }^{206}$

Identifying companies with such outstanding directors is not as easy as it should be (though the original data is in public securities filings). ${ }^{207}$ You might expect them to be identified by activist shareholders in contested director elections squaring off with incumbents. But such fights often pivot instead on specific strategy and executive leadership and the challengers rarely acquire large stakes on spec.

It would be helpful if large institutional investors rated director share ownership highly in their assessments, but that is unfortunately not the case. The guidelines of many indexers and advisors, for instance, emphasize

\footnotetext{
${ }^{202}$ Id. at $43-44$

${ }^{203} I d$. at 44.

${ }^{204}$ See "Letter of Donald Graham to Shareholders of the Washington Post Co." (2003), reprinted in Lawrence A. Cunningham, Dear Shareholder (Petersfield: Harriman House, 2020).

178A Warren Buffet, “The Superinvestors of Graham and Doddsville,” Hermes, 1984. ${ }^{205}$ Warren Buffet, The Superinvestors of Graham and Doddsville, HERMES, 1984.

${ }^{206}$ Meet Fortive: Board of Directors, ForTIVE, https://fortive.com/meet-fortive\#board, (last visited Sep. 15, 2021); Directors: Alan Spoon, IAC, https://www.iac.com/directors/alanspoon (last visited Sep. 14, 2021).

${ }^{207}$ Proxy statements disclose director ownership in a section entitled "Security Ownership of Certain Beneficial Owners and Management" found in a company's annual proxy statement (Schedule 14A). SEC forms 3, 4 and 5, as well as Schedule 13D and 13G, also track corporate insider transactions.
} 
instead features such as director independence from management, meeting attendance records, and number of other boards a director serves on. ${ }^{208}$

The governance community has successfully advocated for corporate policies requiring or exhorting minimum director stock ownership. A common benchmark is to own shares worth triple the annual board retainer, within a few years of starting service-a goal increasingly facilitated by board compensation paid in shares. ${ }^{209}$

While this is probably desirable, the strongest signal of alignment is directors who, on their own rather than due to company policy, buy substantial stakes in their company. The logic is as easy as the simple slogan "we eat our own cooking."

Why might indexers and other critics universally condemn corporate practices that QSs accept and that may enhance a company's performance? Different business models may explain: indexers address the market as a whole while QSs focus on specific companies.

Indexers prescribe policies expected to benefit the overall market, on average, not particular businesses. The size and reach of indexerscommanding around one-third of public equity-give them outsized influence, and a wide critical following. But they have small stewardship staffs and minuscule budgets to address particular companies, according to research by Lucian Bebchuk and Scott Hirst-no more than 45 people covering well more than 3,000 U.S. companies. ${ }^{210}$

QSs appreciate that indexers may present "best practices" in general. Yet without examining context, some companies will not get the governance that is best for them. The indexing business model makes one-size-fits-all governance an imperative. But that should not stop QSs or companies from fashioning a tailored approach.

\section{Director Diversity ${ }^{211}$}

A broader consensus seems to support director share ownership and board diversity, as these are advocated by many different kinds of shareholders, especially indexers, and fully embraced by QSs. But there are important differences in emphasis or approach.

\footnotetext{
${ }^{208}$ See generally ISS United States Procedures \& Policies (Non-Compensation) Frequently Asked Questions, April 21, 2021 (showing general guidance regarding how ISS analyzes certain issues and determines recommendations for companies).

${ }^{209}$ See Lucian A. Bebchuk \& Roberto Tallarita, The Illusory Promise of Stakeholder Governance, 106 CoRnell L. REv. 91, 141-43 (2020). See also, e.g., ISS United States Procedures \& Policies (Non-Compensation) Frequently Asked Questions 22 (2021). ${ }^{210}$ Bebchuk \& Hirst, supra note 6, at 2077-78.

211 This section is adapted from Lawrence A. Cunningham, Opinion: S\&P Corporate Boards Lack Diversity, but theses top companies are leading change - and the stock market rewards them, MARKETWATCH (Oct. 24, 2020, 9:38 AM)

https://www.marketwatch.com/story/sp-500-corporate-boards-lack-diversity-but-these-topcompanies-are-leading-change-and-the-stock-market-rewards-them-2020-10-23; in turn drawing on Lawrence A. Cunningham, Board Gender Diversity: Debate and Practice, 63 CANADIAN Bus. L. J. 244 (2020).
} 
Companies appeared to react under public compulsion when adding diversity to boards in the aftermath of the national conversation on race sparked during the tumultuous summer of $2020 .{ }^{212}$ Due attention zeroed in on racial and gender inclusion across the nation's boardrooms. You'll see both progress and challenges. One discovery: QSs appreciate board diversity.

Few dispute that there has been female and minority underrepresentation on corporate boards compared to the population. Although $13.4 \%$ of the U.S. population are Black, close to 200 companies in the S\&P 500 have no Black director and only $8 \%$ of that cohort's directors are Black, based on data collated by Institutional Shareholder Services analyzed by the QSI. ${ }^{213}$

While every S\&P 500 board has at least one female director today, women hold a little over $25 \%$ of the total seats. ${ }^{214}$ Among the broader Russell 3000 , just over $24 \%$ of seats are held by women, although $61 \%$ of those companies have $20 \%$ or more female members, according to the advocacy group 5050 Women on Boards. ${ }^{215}$

All these percentages are up from a decade ago, ${ }^{216}$ and there is reasoned debate over the pace of change. But disagreement rages on the causes of underrepresentation. Among disputed causes: lack of prioritization by boards; gender and racial stereotypes or in-group bias, and underrepresentation of women or minorities in traditional pools or pipelines (which may, in turn, owe to stereotypes and biases). ${ }^{217}$

One reason the rate of progress is slower than some desire may be the mixed rationales for the quest. There are two broad potential rationales for board diversity: (1) the quantifiable economic interests of corporations and their shareholders, and/or (2) the qualitative social aspects of group decision-making and intuitions of fairness.

\footnotetext{
${ }^{212}$ See Veronica Root Martinez \& Gina-Gail S. Fletcher, Equality Metrics, 130 YALE L. J. F. 869, 884-85 (2021).

${ }^{213}$ Quality Shareholders Initiative, QSI Database of Quality Shareholders (on file with the author and the QSI).

${ }^{214}$ Jeff Green, Women Gained 22 Seats on S\&P 500 Boards in January Surge, BLOOMBERG (Feb. 23, 2021, 6:05 AM), https://www.bloomberg.com/news/articles/2021-02-23/womengained-22-seats-on-s-p-500-boards-in-january-surge; see also Lawrence A. Cunningham, Board Gender Diversity: Debate and Practice, 63 CAN. Bus. L. J. 244 (2020).

${ }^{215}$ Gender Diversity Index First Quarter 2021 Key Findings, 5050 WOMEN ON BOARDS, at 1, https://5050wob.com/wp-content/uploads/2021/07/Q1-2021-

Infographic_Final_EQUILAR.pdf (last visited Sept. 20, 2021); 2020 Women On Boards Gender Diversity Index: 2020 Progress of Women Corporate Directors by Company Size, State and Industry Sector, 5050 WOMEN ON BOARDS, at 3, https://5050wob.com/wpcontent/uploads/2021/02/2020-Gender-Diversity-Index-Report-FINAL.pdf (last visited Sept. 20, 2021). See also Akin Gump Strauss Hauer \& Feld LLP, Top 10 Topics for Directors: Board Diversity, NEwSTEX (Feb 06, 2020).

${ }^{216}$ See Akin Gump Strauss Hauer \& Feld LLP, supra note 215. See also Lisa M. Fairfax, The Bottom Line on Board Diversity: A Cost-Benefit Analysis of the Business Rationales for Diversity on Corporate Boards, 2005 WIS. L. REV. 795, 799-800 (2005).

${ }^{217}$ See, e.g., Fairfax, supra note 216, at 799-810.
} 
Empirical research on whether diversity improves corporate economic performance is equivocal. Numerous studies find a positive association between gender diversity and economic performance, including those of Catalyst and Morgan Stanley Research. ${ }^{218}$ But almost none find any causation, according to a comprehensive survey by Deborah Rhode and Amanda Packel. ${ }^{219}$

The data may reflect how high-performance leads to diversity, as much as that diversity leads to high performance. Testing the effects of board diversity on economic performance is complicated by the variety of relevant contexts to consider - such as board and company size, geography or industry - as well as the variety of board settings, such as addressing acquisitions, dividends, executive pay, financial reporting or corporate culture.

The social case is more compelling. ${ }^{220}$ First, the strongest general argument for board diversity is simple: the best group decisions result from a number of people with a wide variety of backgrounds viewing an issue from many angles. ${ }^{221}$ It is also clear that boards should reflect a corporation's various constituents, meaning diversity not only of race and gender but varying ethnic, cultural and other personal characteristics. ${ }^{222}$

Mere tokenism won't suffice. Investor groups suggest that only with a minimum representation of at least $20 \%$ do contributions of outsider groups cease being representative of that group but get judged on merit. ${ }^{223}$ That occurs more readily when members are selected voluntarily rather than by compulsion. ${ }^{22}$ That's one reason why legal diversity quotas, such as California has enacted for companies headquartered there, ${ }^{225}$ may miss their mark.

\footnotetext{
${ }^{218}$ See, e.g., David A. Carter et al., Corporate Governance, Board Diversity, and Firm Value, 38 Fin. Rev. 33, 36 (2004). CATAlyst, Bottom Line: Connecting Corporate PERFORMANCE AND GENDER DIVERSITY 1 (2004); Why Diversity and Inclusion Matter (Quick Take), CATALYST (June 24, 2020), https://www.catalyst.org/research/why-diversityand-inclusion-matter/; Eva T Zlotnicka et al., Sustainable and Responsible: A Framework for Gender Diversity in the Workplace, MoRgan StAnLEy RsCH., Mar. 31, 2016, at 2. ${ }^{219}$ Deborah L. Rhode \& Amanda Packel, Diversity on Corporate Boards: How Much Difference Does Difference Make?, 39 DEL J. CoRP. L. 377, 390 (2014); see also Amanda K. Packel, Government Intervention into Board Composition: Gender Quotas in Norway and Diversity Disclosures in the United States, 21 STAN. J. L. \& Bus. 192, 201 (2016) (reviewing AARON A. DHIR, CHALlENGING BOARDROOM HOMOGENEITY (2015)).

${ }^{220}$ See, e.g., CATAlyst, supra note 218. See also Fairfax, supra note 216, at 810-11.

${ }^{221}$ See Fairfax, supra note 216, at 831-32.

${ }^{222}$ See id. at 820, 21.

${ }^{223}$ See e.g., 30\% Club Canadian Investor Group, Statement of Intent, (Sept. 2017), https://30percentclub.org/assets/uploads/30_percent_Club_Canadian_Investor_Statement_U pdated_May_2019_v2.pdf.

${ }^{224}$ See generally Kenneth R. Ahern \& Amy K. Dittmar, The Changing of the Boards: The Impact on Firm Valuation of Mandated Female Board Representation, Q. J.OF ECON. 137, 139-140 (2012) (noting that forced board diversity may lead to underexperienced individuals being appointed to boards and can adversely affect firm value).

${ }^{225}$ Assemb. B. No. 979 (Cal. Sept. 30, 2020).
} 
As for what shareholders might think, the QSI ranks most of those identified by the 2020 Women on Boards as having the greatest percentage of women directors. Among those, $70 \%$ are in the top half for QS density. ${ }^{226}$ The nineteen in the top decile are listed in Table III.4.

\begin{tabular}{|l|l|}
\hline Alliant Energy & Johnson \& Johnson \\
Am. States Water & Kaiser Aluminum \\
American Tower & Pepsico \\
Am. Water Works & Sensient Technologies \\
Arthur J. Gallagher \& Co. & Stryker Corporation \\
Associated Banc-Corp. & Sysco Corporation \\
Eli Lilly \& Company & Walt Disney Company \\
Estee Lauder Companies & Waters Corporation \\
HNI Corporation & Xcel Energy, Inc. \\
Intl. Flavors \& Fragrances &
\end{tabular}

Table III.4: Women on Boards and QS Density

Concerning Black directors, the QSI crunched the data from Institutional Shareholder Services of S\&P 500 companies. One notable finding: a select group of such companies boasts three Black directors over the past few years, all representing at least $20 \%$ of the board. All nine of those companies also in the QSDR rank in the top half, as listed in Table III.5. 227

\begin{tabular}{|l|l|}
\hline DTE Energy & Public Service Enter. \\
Eversource Energy & Southern Co. \\
Marriott & Verizon \\
Nike & WEC Energy \\
Omnicom Group & \\
\hline
\end{tabular}

Table III.5: Black Directors on Boards and QS Density

What might explain these associations? The correlation between QS density and diversity, of both gender and race, may be due to the long-term horizons of QSs. Compared to the short-term view of transient shareholders, QSs benefit more from the multiple viewpoints on boards that come from diversity.

The association between QS density and multiple Black directors on a board may reflect the focused investment approach of QSs. Indexers, who own small stakes in every company, may have to be content with quota-type

\footnotetext{
226 The 2020 Women on Boards' Honor Roll Companies for 2017 include 176 companies that have been Winning 'W' Companies for seven consecutive years, 2011-2017. Of those 176 companies, 133 appeared in the QSDR. Among those, 70\% of the honorees were in the top half in the QSDR (92/133), 40\% were in the top quarter (54/133), and $15 \%$ were in the top decile (19/133). See calculations infra Appendix B.

${ }^{227}$ From ISS data, we selected all Black directors holding office during 2018 or 2019 or both, eliminated duplicate names, then listed the companies, and, using a word count function, counted the companies appearing most, then went to their websites to verify the composition of their current boards.
} 
guidelines advocating one minority director per board. QSs, who focus on particular companies, care about individual identities, which may result in greater diversity than a quota system would yield.

There may be a long way to go on board gender and racial diversity, and it remains true that the social case is stronger at present than the economic one. Everyone also agrees that director quality remains paramount. But these observations do suggest that America's best shareholders and board diversity go hand-in-hand.

\section{E. What Else Matters?}

The prevailing literature on corporate governance-as well as ESG and other variations - seem to fixate attention on variables whose reliability is now contested and whose relevance is put in doubt by the QSI research. Beyond such topics reside many of greater interest to QSs and that therefore should be of greater interest to researchers and scholars. The following highlights four examples of what matters most that's been examined least.

1. Capital Allocation. ${ }^{228}$ Effective capital allocators put every corporate dollar to its highest use, from organic or acquired growth to share buybacks or dividends. They do so with an investors' mindset that all managers and shareholders would profit from understanding.

An elite group of 167 exceptional capital allocators is identified in research by Professor George Athanassakos. ${ }^{229}$ The study ranks companies by capital allocation success and then compares portfolios comprised of those at the top versus the bottom. ${ }^{230}$ On average, the superior allocator portfolio outperformed the inferior one by $33 \%$, in terms of cumulative threeyear returns, over several recent decades. ${ }^{231}$

Most such companies are also in the QSDR. Among companies on both lists, the capital allocators rank disproportionately high for QS density: $26 \%$ in the top decile of QS density; $56 \%$ in the top quarter; and $75 \%$ in the top half. Here is a sampling of companies topping the combined lists of deft allocators and QS density:

\begin{tabular}{|l|l|}
\hline Amphenol Corp. & Jack Henry \& Assocs. \\
\hline
\end{tabular}

\footnotetext{
${ }^{228}$ This sub-section is adapted from Lawrence A. Cunningham, Opinion: Why companies that spend their capital wisely are smart places for your money, MARKETWATCH (Oct. 31, 2020, 9:31 AM), https://www.marketwatch.com/story/these-savvy-companies-know-thatdoing-this-one-thing-well-is-the-secret-to-attracting-long-term-stable-shareholders-2020-1029.

${ }^{229}$ See George Athanassakos, Do Value Investor CEOs Outperform? (April 20, 2020) (unpublished working paper) (on file with Western University). The assertion in the text is based on comparing the companies identified by Professor Athanassakos as led by exceptional capital allocators to the QSDR. Of the 167 companies identified by Professor Athanassakos, 140 are in the QSDR. Among those, 26\% are in the top 10\% of the QSDR; $56 \%$ are in the top quarter; and $75 \%$ are in the top half. See also Athanassakos, supra note 229.

${ }^{230}$ See Athanassakos, supra note 229.

${ }^{231} I d$.
} 


\begin{tabular}{|l|l|}
\hline Ansys Inc. & Moody's Corp. \\
Balchem Corp. & Roper Technologies Inc. \\
Danaher Corp. & Stryker Corp. \\
Illinois Tool Works & Texas Instruments \\
\hline
\end{tabular}

Table III.6: Capital Allocation and QS Density

What sets these managers and shareholders apart? Their emphasis differs from quarterly earnings per share (EPS) favored by traders or market capitalization that's of interest to indexers. They stress instead intrinsic value, long-term performance metrics such as return on invested capital (ROIC), and analytics like internal rate of return (IRR).

ROIC is a good way to measure capital allocation effectiveness. At the corporate level, a good proxy takes bottom line performance, such as annual net income, as a percentage of average capital invested by shareholders. Individual projects are evaluated in terms of IRR, starting with capital expenditures to expand existing businesses as well as research and development budgets. ${ }^{232}$

Successful capital allocators are especially cautious when it comes to acquisitions. ${ }^{233}$ They insist on paying a price below a target company's intrinsic value and delivering an expected return that exceeds a preset hurdle rate. Such an investor mindset guards against managerial appetites for empire building and temptations of rosy forecasts about synergies, which often lead to acquisitions that destroy capital.

On share buybacks, some favor them because they increase earnings per share simply by reducing shares outstanding. That may boost incentivebased pay for managers and spur stock price for traders ready to cash in. But capital allocators see buybacks as investments. To them, buybacks are rational only when price is below a conservative estimate of per share intrinsic value. (That's why they shun buyback quota programs.)

Finally, on dividends, many capital allocators see them as rational only whenever other uses of capital — such as reinvestment, acquisitions or buybacks - are unattractive. ${ }^{234}$ To many, all excess capital should be returned to the shareholders - no cash hoarding.

Others recognize that dividend policy shapes the shareholder base. A no-dividend policy may suit a largely taxable shareholder base while regular dividends give shareholders a reason to stay put in troubled times. Regular dividends can lengthen holding periods, marginalizing transients, and induce larger positions, marginalizing indexers.

\footnotetext{
${ }^{232}$ Lawrence A. Cunningham, Opinion: Why Companies That Spend Their Capital Wisely Are Smart Places for Your Money, MARKETWATCH (Oct. 31, 2020, 9:31 AM), https://www.marketwatch.com/story/these-savvy-companies-know-that-doing-this-onething-well-is-the-secret-to-attracting-long-term-stable-shareholders-2020-10-29.

${ }^{233}$ Id at 3.

${ }^{234} I d$.
} 
2. Sustainable Moats. ${ }^{235}$ Companies that attract a high density of QSs tend to boast competitive advantages that protect business performance against a variety of threats. Often referred to as moats, these include economies of scale, credence value, intellectual property, network effects, distribution systems, and brand strength. ${ }^{236}$

Morningstar publishes a list of some 500 companies regarded as having among the strongest moats, 200 of which are in the QSDR database. ${ }^{237}$ Of those 200 companies common to both, one-third are in the top decile of the QSDR; two-thirds are in the top quarter; and the overwhelming majoritynearly $90 \%$ - are in the top half. This confirms widely known anecdotal evidence that moats attract QSs. Table III.7 lists companies topping both lists:

\begin{tabular}{|l|l|l|}
\hline Roper & VeriSign & ADP \\
Stryker & Colgate-Palmolive & Eli Lilly \\
Jack Henry & Accenture & Mastercard \\
Moody's & $3 \mathrm{M}$ & Domino's Pizza \\
\hline
\end{tabular}

Table III.7: Moats and QS Density

Among moats, brand strength appears to be a particular magnet for QSs. There is a strong association between managers regarded as the best stewards of great brands and QSI rankings. For instance, among U.S. managers ranked in the global elite for brand guardianship, virtually all are in the top half of the QSI rankings. ${ }^{238}$ Table III.8 lists exemplars.

\begin{tabular}{|l|l|l|}
\hline Amazon & FedEx & P\&G \\
Cisco & Home Depot & UnitedHealth Group \\
Disney & IBM & Visa \\
Estee Lauder & Johnson \& Johnson & Walmart \\
\hline
\end{tabular}

235 This sub-section is adapted from Lawrence A. Cunningham, Opinion: Wanted: Stock Investors with Time and Money to Support Profitable, Well-Run Companies, MARKETWATCH (Oct. 24, 2020, 1:22 PM), https://www.marketwatch.com/story/are-you-astock-investor-with-time-and-money-these-top-companies-want-you-2020-10-20 and Lawrence A. Cunningham, Opinion: Why Companies That Spend Their Capital Wisely Are Smart Places for Your Money, MARKETWATCH (Oct. 31, 2020, 9:31 AM),

https://www.marketwatch.com/story/these-savvy-companies-know-that-doing-this-onething-well-is-the-secret-to-attracting-long-term-stable-shareholders-2020-10-29.

${ }^{236}$ See Kanuri \& McLeod, Sustainable competitive advantage and stock performance: the case for wide moat stocks, 48 APPLIED ECONOMICS 5117, 5119 (2016).

${ }^{237}$ Wide-Moat Focus Index, MORNINGSTAR, https://www.morningstar.com/bestinvestments/wide-moat-focus.

238 The list of the top 100 brand managers is taken from Global 5002019 The Annual Report on the World's Most Valuable Brands, BRAND FinANCE 36-37 (Jan. 2019), https://brandfinance.com/wp-content/uploads/1/global_500_2019_locked_4.pdf ("Brand Guardianship Index"). Of the 38 U.S. managers on the Brand Guardian Index, 36 of them are in the QSDR. Among those, more than one-third are in the top 10\% of the QSDR; $75 \%$ are in the top quarter; and $97 \%$ are in the top half. 


\section{Table III.8: Brands and QS Density}

A more intriguing reason why high densities of QSs are associated with corporate outperformance is that the QS cohort is itself a source of competitive advantage, akin to network effects. These arise when a system's value increases as more people use it. In most cases, network effects represent a tangible benefit to customers, as with fax machines in the old days and social media today.

Similar advantages can arise from a network of QSs. As a group, QSs are more likely than other major shareholder cohorts -- such as indexers or transients -- to care about the identity of fellow shareholders. This "birds of a feather" effect is visible among the companies held by leading QSs, such as those listed in Table III.9.

\begin{tabular}{|l|l|l|}
\hline $\begin{array}{l}\text { Baker Brothers } \\
\text { Baupost Group } \\
\text { Berkshire Hathaway } \\
\text { Blue Harbour }\end{array}$ & $\begin{array}{l}\text { Cantillon Capital } \\
\text { Capital Research Global } \\
\text { Fiduciary Management } \\
\text { Gates Foundation }\end{array}$ & $\begin{array}{l}\text { Kensico Capital } \\
\text { Lone Pine Capital } \\
\text { Southeastern } \\
\text { Temasek Holdings }\end{array}$ \\
\hline
\end{tabular}

Companies tap into the broader QS ecosystem, where members tend to know one another or know of one another. Resulting network effects reinforce advantages of a high-density QS base of patient and knowledgeable shareholders.

The QS cohort may also help brand a company. After all, consumer brands become competitive advantages when they assure that consumers recognize product features. A corporate reputation for attracting QSs is a competitive advantage when a company repeatedly commits to the values patient focused shareholders appreciate, including long-term performance metrics and rational capital allocation policies.

3. Annual Letters to Shareholders. ${ }^{239}$ Investors ask what resources to consult when hunting for great companies. Good advice is to read the shareholder letter the company sends out every year. Next to the financial figures, it is perhaps the most important and accessible source of valuable information. These communications reveal a lot about a company and its CEO. Some obfuscate, others patronize, and many appear to be ghostwritten, but the best ones share business insights that help readers understand a company.

Numerous surveys of shareholder letters rank them according to various indicators of quality, some statistical and some judgmental. Despite such variety, the same names appear often in both published lists and private polls - invariably starting with Buffett - and they tend to attract a high level

239 This sub-section is adapted from Cunningham's Quality Investing columns in MarketWatch of November 4, 2020. 
of QSs. One expert on corporate shareholder letters, Laura Rittenhouse, in a recent annual ranking, designated the top 25 by her measures, the vast majority of which rank among the highest in terms of attracting QS."240

\begin{tabular}{|l|l|l|}
\hline ADP & CVS & Microsoft \\
Amazon.com & Edison International & Netflix \\
Becton, Dickinson & General Mills & Sherwin-Williams \\
Charles Schwab & General Motors & Southwest Airlines \\
Clorox & Google & Texas Instruments \\
Costco & Honeywell & Travelers \\
& Lockheed Martin & \\
\hline
\end{tabular}

4. Long-Tenured CEOs. ${ }^{241}$ Companies boasting the longest tenured CEOs also tend to attract QSs. In recent years, the average CEO tenure of large U.S. public companies has risen to ten years from seven (the average varies year-to-year and across statistical methods). ${ }^{242}$ Many CEOs create greatest value during the "golden" years 11- to 15, when knowledge and experience may be optimal. ${ }^{243}$ Some experts suggest 10 years may be ideal for most: long enough to contribute a lot, but short enough to avoid complacency. ${ }^{244}$

The QSI identified CEOs with tenures of at least 10 years as of the beginning of 2020 from the QSDR. Of the 100 companies making the cut, one-fourth of the long-tenured CEOs ranked in the top decile for attracting QSs, one-half in the top quarter, and almost all (85) ranked in the top half. In other words, long-tenured CEOs are associated with high-quality shareholders.

The longevity/quality correlation is particularly robust for companies with a tradition of long CEO tenures - one long-serving CEO followed by one or more others. Leading examples: EcoLab has had seven CEOs in its 99-year history; Emerson Electric has had three CEOs over the past 66 years; and Amphenol whose current and prior CEO together served 25 years (Richard Norwitt and Martin Loeffler).

\footnotetext{
${ }^{240}$ See Rittenhouse Rankings Press Release, Companies Excelling in Rittenhouse Candor Analytics $^{\text {TM }}$ Substantially Outperform the Market in 2016 (December 13, 2016). The assertion in the text is based on comparing the listing in Rittenhouse Rankings to the QS density rankings contained in QS Density Ranking, described in Section II.

${ }^{241}$ This sub-section is adapted from Lawrence A. Cunningham, Opinion: Long-Tenured CEOs Can Take a Business from Good to Great - and these Companies Have Them, MARKETWATCH (Apr. 14, 2021), https://www.marketwatch.com/story/long-tenured-ceoscan-take-a-business-from-good-to-great-and-these-companies-have-them11618380952 ? mod=quality-investing.

242 Chip Cutter, New Thinking Emerges on Optimal Tenure for a CEO, WALL STREET JOURNAL 4-5 (February 3, 2020).

${ }^{243}$ See James M. Citrin et al. The CEO Life Cycle, HARv. Bus. Rev. (2019), available at https://www.spencerstuart.com/-/media/2019/hbr-ceo-

lifecycle/hbr_ceo_lifecycle_spencerstuart.pdf.

${ }^{244}$ See, e.g., Cutter, supra note 242.
} 
CEOs come and go for many reasons - from retirement or better job opportunities to ouster due to subpar performance or a bad business model. But it's hard to stick around without sustained long-term performance - and a supportive shareholder base. What seems to unite this cohort of long tenures with high QS density is a shared appreciation for longterm value creation: the CEO has a long-term vision for success and QSs are prepared to see it through with the company.

\section{CONCLUSION}

The Quality Shareholders Initiative builds on impressive research into shareholder demographics and behavior. Continued probing of this cohort will be increasingly valuable as U.S. shareholders exercise their voting power on the increasingly important topics facing them, whether firmspecific mergers and board elections to broader social topics of diversity and climate change. Further research opportunities in this area are vast.

For instance, it is possible that not all QSs behave in a similar way. Might it be that there are two different kinds of QS? Might some exercise their position for positive corporate good while others do so to extract private gain? Skimming the lists of top and bottom performers with high QS density, what is the exact makeup and behavior of this cohort? Consider inside ownership by a single executive and his/her family versus other forms of QSs such as insurance companies or mutual funds. In other words, not all long-term high conviction ("LTHC") shareholders are QSs.

Some LTHC's exert influence or control to benefit themselves at the expense of other shareholders. Research could examine the effects of high levels of inside ownership or the presence of controlling shareholders on both relative QS density and relative corporate performance. If so, under the QS rubric, the designation of QS would be retained for the symbiont portion of the LTHC quadrant, while calling out the parasitic portion of the quadrant and specifically excluding them. (Consider it the inverse of the "indexer and closet indexer" to be the "true QS and the phantom QS".)

In addition, further tools and techniques can be refined to deal with some of the definitional challenges of Quality Shareholders. Despite taking care to delineate a range of metrics probing conviction, gaps may remainfor instance, concentration is almost certainly an imprecise measure of conviction. Consider two reciprocal examples of the problem from real world settings.

First, a mutual fund family might seed a dozen funds, each heavily concentrated (say 5-10 stocks); a few years on, some of these naturally outperform without effort and fund markets these to attract AUM. This might pass most statistical definitions for the conviction aspect of QS, but it is the fund family's behavior is inconsistent with the philosophy or reasons for 
empowering certain shareholders. Such strategies could even be used as a subterfuge to game the system.

Empirical research could continue to refine the definitions or develop or other tools to distinguish genuine QS from such phantom QS. Policy and practice research could do so by drafting language for charter provisions that express the purpose of QS empowerment, defines terms accordingly. Language would then put the burden of persuasion on the shareholder wishing to exercise associated rights to prove eligibility to the corporation's satisfaction, that it is a genuine QS rather than a strategic artifact or subterfuge.

For the reciprocal case, some institutional investors employ high conviction managers who would be QSs but also impose limits on permissive positions. Forced sales can result to reduce average holding periods or concentration thresholds, though not the manager's conviction. Such effects might disqualify such shareholders from exercising QS rights, though they may be expected to exercise those rights more suitably than fellow shareholders who met the numerical QS thresholds. For theory, this is less worrisome in a sense because they almost entirely ceased to be shareholders for whatever reason; for practice, research might investigate whether corporations offering additional rights in such settings might, as a matter of theory or practice, induce such funds to alter their restrictions.

Further research could contract the scope to consider whether particular industries or segments attract QSs or expand the scope to consider the shareholder demographics in other leading industrial countries, such as France, Germany, Italy, Japan, and the United Kingdom.

Research into the policies and practices that may attract or repel different shareholder types remains of great ongoing interest.

For instance, we are investigating the correlation between QS density and various measures of competitive advantage and of insider share ownership. Similarly, refinements can be made in the scope of the definition of QS. For instance, we are examining the degree to which various shareholders vote on corporate resolutions based on their own independent judgment as compared with reliance upon the recommendations of institutional investor proxy advisers such as ISS or Glass Lewis. Performance results and implications warrant continued examination. Our initial research is the product of hindsight. A more convincing test would be longitudinal. A research proposal that Cunningham and the Initiative aim to implement: construct a portfolio of high QS density investments, chosen ex ante, with performance results to be isolated and reported five years hence.

In constructing such a portfolio, in addition to fundamental analysis, it is worth trying to determine whether any of the various levers noted earlier are more (or less) frequently used by the top (and bottom) performers. If so, portfolio design could be weighted in favor of companies applying such 
levers. The QSI respectfully encourages and welcomes further research into this topic likely to be of increasing importance. 


\begin{tabular}{l}
\hline QS Firms \\
AKO Capital \\
Akre Capital \\
Ariel Investments \\
Aristotle Capital \\
Artisan Partners \\
Atlanta Investment \\
Avenir Corp. \\
Baillie Gifford \& Co. \\
Baker Brothers \\
Baron Funds \\
Barrow Hanley \\
Baupost \\
Beck, Mack \& Oliver \\
Blue Harbour \\
Brandes \\
Broad Run \\
Brown Bros. Harriman \\
Burgundy Capital \\
Cantillon Capital \\
Capital Research \\
Capital World \\
Cedar Rock \\
Davis Selected Advisers \\
Diamond Hill \\
D.F. Dent
\end{tabular}

Dodge \& Cox

Douglass Winthrop

E. S. Barr

Eagle Capital

Ensemble Capital

Fiduciary Mgmt.

Findlay Park

First Manhattan

First Pacific

Franklin Mutual

Gardner Russo

Giverny Capital

Fundsmith

Harris Assoc. (Oakmark)

Hartford Funds

Hotchkiss \& Wiley

Irdian Asset Mgmt.

Jackson National Asset

Kahn Brothers

Kensico Capital

Klingenstein Fields

Lafayette Investments

Lee, Danner \& Bass

London Co. of Virginia

Longview Partners

Lourd Capital

Lyrical Asset Mgmt.
Mar Vista

Massachusetts Financial

Matrix Capital

Medley Brown

Mraz, Amerine

Neuberger Berman

Polen Capital

Ruane Cunniff

Scopia Capital

Sleep, Zakaria

Smead Capital

Southeastern Asset Mgmt.

Speece Thorson

Sprucegrove

State Farm Insurance

Stockbridge Partners

T. Rowe Price

Temasek Holdings

Tweedy Browne

W. H. Reaves

Wallace Capital

Water Street Capital

WCM

Wedgewood Partners

Weitz Inv. Mgmt.

Wellington

Westport

\begin{tabular}{ll|}
\hline QS Attractors & \\
\hline 3M & Credit Acceptance \\
Abbott Labs & Crown Holdings \\
Accenture & Danaher \\
Air Products & Dover \\
Alleghany & Enstar \\
Alphabet (Google) & Genuine Parts \\
Amazon & Graham Holdings (WaPo) \\
Amerco (U-Haul) & Hormel Foods \\
American Tower & Illinois Tool Works \\
Anthem & Intel \\
AutoNation & Johnson \& Johnson \\
Berkshire Hathaway & Kimberly Clark \\
Bristol-Myers Squibb & Liberty Media \\
Brookfield & Loews \\
Cable One & Markel \\
Capital One & Marsh \& McLennan \\
CarMax & Mastercard \\
Churchill Downs & Microsoft \\
Clorox & Mohawk Indus. \\
Coca-Cola & Morningstar \\
Constellation Brands & Nestlé \\
\hline
\end{tabular}

\section{Netflix}

NVR

O'Reilly Automotive

PepsiCo

PNC Financial

Post Holdings

Procter \& Gamble

Progressive Corporation

Roper Technologies

Seaboard

Sherwin Williams

Sirius

Texas Instruments

Thermo Fisher

TransDigm

Unilever

United Technologies

Verisign

Walmart

White Mountains Ins. 



\section{APPENDIX B}


The following abstract summarizes the various correlation data discussed at various points throughout the Article. The left column lists the practice or policy discussed and the right column indicates where in the Article the related data is discussed in context. Statistics-wise, the first column gives the number of observations in the respective correlation test, followed by the number and percent, respectively, of such observations that were within the top $10 \%$, top $25 \%$, and top $50 \%$ of the QSDR. 


\begin{tabular}{|c|c|c|c|c|c|c|c|c|}
\hline \multirow[b]{2}{*}{ Practice/Policy } & \multirow[t]{2}{*}{ No. } & \multicolumn{3}{|c|}{$\begin{array}{c}\text { Number Within } \\
\text { QSDR }\end{array}$} & \multicolumn{3}{|c|}{$\begin{array}{c}\text { Percent Within } \\
\text { QSDR }\end{array}$} & \multirow[b]{2}{*}{$\begin{array}{l}\text { Location } \\
\text { in Article }\end{array}$} \\
\hline & & $\begin{array}{r}\text { Top } \\
10 \% \\
\end{array}$ & $\begin{array}{r}\text { Top } \\
25 \% \\
\end{array}$ & $\begin{array}{r}\text { Top } \\
\mathbf{5 0 \%} \\
\end{array}$ & $\begin{array}{l}\text { Top } \\
10 \%\end{array}$ & $\begin{array}{r}\text { Top } \\
\mathbf{2 5 \%} \\
\end{array}$ & $\begin{array}{r}\text { Top } \\
\mathbf{5 0 \%} \\
\end{array}$ & \\
\hline $\begin{array}{l}\text { Bd. Diversity- } \\
\text { Race }\end{array}$ & 9 & 1 & 8 & 9 & $11 \%$ & $89 \%$ & $100 \%$ & $\begin{array}{l}\text { n.227; } \\
\text { TIII.5 }\end{array}$ \\
\hline $\begin{array}{l}\text { Time-Weighted } \\
\text { Voting }\end{array}$ & 5 & 0 & 0 & 5 & $0 \%$ & $0 \%$ & $100 \%$ & n.196 \\
\hline Branding & 36 & 13 & 27 & 35 & $36 \%$ & $75 \%$ & $97 \%$ & $\begin{array}{l}\text { n.238: } \\
\text { TIII.8 }\end{array}$ \\
\hline Trust & 49 & 13 & 33 & 45 & $26 \%$ & $67 \%$ & $90 \%$ & n. 155 \\
\hline Moat & 202 & 65 & 127 & 180 & $32 \%$ & $62 \%$ & $87 \%$ & $\begin{array}{l}\text { n.237; } \\
\text { TIII.7 }\end{array}$ \\
\hline Split-Chair & 216 & 37 & 92 & 184 & $16 \%$ & $40 \%$ & $85 \%$ & n.166 \\
\hline Chair-CEO & 234 & 66 & 132 & 197 & $28 \%$ & $57 \%$ & $84 \%$ & n.166 \\
\hline Drucker & 141 & 39 & 76 & 119 & $28 \%$ & $54 \%$ & $84 \%$ & n.91 \\
\hline Bus. R. Table & 135 & 34 & 74 & 109 & $25 \%$ & $55 \%$ & $81 \%$ & n.92 \\
\hline ESG-Barron's & 47 & 10 & 24 & 38 & $20 \%$ & $50 \%$ & $80 \%$ & n.107 \\
\hline ESG--IBD & 46 & 11 & 23 & 38 & $23 \%$ & $50 \%$ & $83 \%$ & n.107 \\
\hline $\begin{array}{l}\text { Capital } \\
\text { Allocation }\end{array}$ & 140 & 37 & 79 & 105 & $26 \%$ & $56 \%$ & $75 \%$ & $\begin{array}{l}\text { n. 229; } \\
\text { TIII.6 }\end{array}$ \\
\hline $\begin{array}{l}\text { Bd. Diversity-- } \\
\text { Women }\end{array}$ & 133 & 19 & 54 & 92 & $15 \%$ & $40 \%$ & $70 \%$ & $\begin{array}{l}\text { n.226; } \\
\text { TIII.4 }\end{array}$ \\
\hline Dual Class & 135 & 15 & 41 & 86 & $11 \%$ & $30 \%$ & $64 \%$ & n. 186 \\
\hline Uni/Class Board & & & & & & & & n. 193 \\
\hline
\end{tabular}

